Estuarine, Coastal and Shelf Science

December 2018, Volume 214 Pages 194-206

http://dx.doi.org/10.1016/i.ecss.2018.09.030

http://archimer.ifremer.fr/doc/00458/56994/

(c) 2018 Elsevier Ltd. All rights reserved.

\title{
Pseudo-nitzschia sp. diversity and seasonality in the southern North Sea, domoic acid levels and associated phytoplankton communities
}

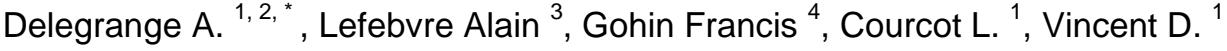

\author{
${ }^{1}$ Univ. Littoral Côte d'Opale, Univ. Lille, CNRS, UMR 8187, LOG, Laboratoire d'Océanologie et de \\ Géosciences, F-62930, Wimereux, France \\ ${ }^{2}$ Ecole Supérieure du Professorat et de l'Education, Lille Nord de France, Communauté d'Universités et \\ d'Etablissements, F-59658, Villeneuve d'Ascq, France \\ ${ }^{3}$ IFREMER, LER/BL, 150 Quai Gambetta, F-62321, Boulogne-sur-Mer, France \\ ${ }^{4}$ IFREMER, DYNECO pelagos, Centre Bretagne, ZI de la Pointe du Diable, CS 10070, F-29280, \\ Plouzané, France \\ * Corresponding author : A. Delegrange, email address : alice.delegrange@espe-Inf.fr
}

\begin{abstract}
:
The diversity, toxicity and seasonality of Pseudo-nitzschia sp. were investigated from February to November 2012 in the southern Bight of the North Sea (SBNS) along the French coast. The identification of Pseudo-nitzschia species in this area was addressed for the first time in this study. Our results revealed a low species richness ( 3 distinct species) in association with moderate $\left(102 \mathrm{pg} \mathrm{mL}^{-1}\right)$ to high (263 $\left.\mathrm{pg} \mathrm{mL}^{-1}\right)$ domoic acid (DA) levels in autumn and spring, respectively.

Pseudo-nitzschia succession corresponded to the dominance of $P$. delicatissima in April-May (86\% of total diatoms) as a co-occurring species of the Phaeocystis globosa bloom. Following the Phaeocystis bloom (May-September), $P$. pungens dominated markedly over $P$. fraudulenta and $P$. delicatissima and was the only species present in autumn, although at low abundance $\left(<1000 \mathrm{cell} \mathrm{L}^{-1}\right)$. The results of this study support the idea that Pseudo-nitzschia seasonality in the SBNS relies principally on temperature and nutrient availability (DIN and silicates), which, in turn, depend on locally fluctuating environmental conditions (rainfalls and winds). This study highlights the potential for the SBNS to be a potential risk area in regard to the possible impacts of DA on marine resources and the DA transfer through marine food webs. This is of particular concern since DA concentration in seawater was not systematically correlated to potentially toxic Pseudo-nitzschia abundance.
\end{abstract}




\section{Highlights}

- Low Pseudo-nitzschia sp. diversity (three species) in the southern North Sea. Domoic acid levels reached $263 \mathrm{pg} \mathrm{mL}^{-1}$ in May 2012, 83\% as dissolved DA. Strong species seasonality driven by temperature and nutrient availability (DIN and silicates). Autumnal DA concentrations could be attributed to $P$. pungens. DA concentration was not systematically correlated to Pseudo-nitzschia spp. abundance.

Keywords : Pseudo-nitzschia, Southern North Sea, Domoic acid, Phaeocystis globosa, Harmful algal blooms (HAB) 


\section{Introduction}

The cosmopolitan diatom genus Pseudo-nitzschia sp. comprises more than 50 species amongst which 24 are known to produce Domoic Acid (DA; Gai et al., 2018; Lundholm, 2018), a potent neurotoxin responsible for Amnesic Shellfish Poisoning (ASP). Since the first reports of ASP in 1987 at Prince Edward Island, shellfish stocks have been systematically monitored to prevent any outbreaks of ASP among humans. Since then, alert indicators such as DA concentration and/or Pseudo-nitzschia sp. abundance monitoring have been shown to be efficient tools, as no human poisoning has ever been reported (Trainer et al., 2012). However, DA poisoning of marine mammals and seabirds can still occur when they feed on DA-contaminated planktivorous prey (e.g. anchovies and sardines; Du et al., 2016; Gibble et al., 2018; Jensen et al., 2015; Lefebvre et al., 2002; Louw et al., 2018; Scholin et al., 2000; Sierra-Beltran et al., 1997; Stauffer et al., 2012). The trend of increasing abundance of Pseudo-nitzschia over the past decade has raised scientific awareness and concerns about public health (e.g. Hernández-Fariñas et al., 2014; Lefebvre et al., 2014; Lundholm et al., 2010; Parsons et al., 2002; Trainer et al., 2012) emphasizing the need to assess its dynamics, and investigate potential DA production in exploited coastal areas. In the English Channel, occurrence of DA in king scallop (Pecten maximus) has been reported several times from south western regions such as the Bay of Seine and the Bay of Brest (Husson et al., 2016). In the Eastern English Channel-North Sea (EEC-NS), reported ASP events were mainly concentrated in the northern regions (Scotland, Norway, Denmark; Trainer et al., 2012) although Pseudo-nitzschia sp. cells are present year-round in the southern regions (Bresnan et al., 2015; Hernández-Fariñas et al., 2014; Schapira et al., 2008; Seuront et al., 2006). Thus, reports of DA and shellfish closures were not recorded in the EEC-NS until 2014, when king scallop stocks off the Bay of Somme (France) were contaminated with DA, which represented the northernmost ASP alert of France (Lefebvre A., pers. com.). Existing studies and 
monitoring surveys often limit the detection of Pseudo-nitzschia sp. to the genus level or to morphological features measurable by optical microscopy, i.e. valve width, distinguishing large species (width $>3 \mu \mathrm{m}$, Pseudo-nitzschia complex seriata), from narrow ones (width $<3$ $\mu \mathrm{m}, P$. delicatissima complex). This distinction by size categories has already made possible seasonal studies within this genus (Bresnan et al., 2015; Brown and Bresnan, 2008; Fehling et al., 2004; Thorel et al., 2017) as well as allowing for analysis of the short and long-term changes in Pseudo-nitzschia with regard to environmental parameters (Díaz et al., 2014; Husson et al., 2016; McKibben et al., 2015).

In the Eastern English Channel and Southern Bight of the North Sea, phytoplankton studies have largely focused on spring bloom periods, revealing that diatoms and the prymnesiophytes Phaeocystis globosa form the bulk of phytoplankton biomass (Bonato et al., 2015; Schapira et al., 2008; Seuront et al., 2006). However, there is still a clear lack of knowledge in this region regarding Pseudo-nitzschia species diversity and seasonality in relation to environmental parameters and DA levels. Finally, studies defining Pseudonitzschia species nutrient and physical requirements and biotic interactions at the regional scale are scarce but crucial to predict proliferation and associated toxicity. Recently, Husson et al. (2016) identified the environmental niche of Pseudo-nitzschia sp. in six distinct bays from Brest to the Seine estuary. In this study, additional data focusing on Pseudo-nitzschia seasonality and diversity in the EEC-NS ecosystem over an annual cycle is provided. The aim is to define their importance in the seasonal phytoplankton succession and to estimate associated DA concentrations with regard to environmental forcing and hydro-biological conditions.

\section{Material and Methods}

2.1 Sampling strategy 
The sampling station ( 10 m depth) was located along the French coast of the southern North Sea, in Dunkirk harbor ( $51^{\circ} 1^{\prime} 12^{\prime \prime}$ N, $1^{\circ} 9^{\prime} 0^{\prime \prime}$ E, Figure 1$)$. The inner part of this harbor forms a small semi-enclosed embayment where semi-diurnal macrotidal tides prevail and enable important water exchanges with coastal waters of the southern North Sea. Sampling was conducted fortnightly from February 22 to November 142012 during flood (within 2 hours before high tide) to consider only neritic plankton communities although benthic communities could be re-suspended during high mixing periods.

Temperature $\left({ }^{\circ} \mathrm{C}\right)$ and salinity were measured with an Aanderaa Instruments probe, turbidity (Turb) with an Eutech instruments waterproof probe, $\mathrm{pH}$ with a HANNA pH probe, and dissolved oxygen $\left(\mathrm{dO}_{2}, \mathrm{mg} \mathrm{L}^{-1}\right)$ with a Handy Polaris Oxyguard probe at each sampling date. Seawater samples were collected at one meter depth using a Niskin bottle. For inorganic nutrients, seawater samples (frozen at $-20{ }^{\circ} \mathrm{C}$ until analysis) were analyzed by either fluorimetry $\left(\mathrm{NH}_{4}{ }^{+}\right.$; Trilogy, Turner Designs; Holmes et al., 1999) or by the use of an autoanalyzer (Alliance Integral Futura) for $\mathrm{NO}_{2}{ }^{-}, \mathrm{NO}_{3}{ }^{-}, \mathrm{HPO}_{4}{ }^{2-}, \mathrm{Si}(\mathrm{OH})_{4}$ following standard protocols (Bendschneider and Robinson, 1952; Mullin and Riley, 1955; Murphy and Riley, 1962). The surface solar irradiance (ssi) was derived from the bi-directional reflectance measured by MSG (METEOSAT Second Generation) and provided by the OSI SAF (Le Borgne et al., 2006). Winds (hourly measurements) and rainfall (daily) data were obtained from the Dunkirk Meteo France station (www.meteofrance.fr).

2.2 Phytoplankton standing stock and community composition

Phytoplankton biomass was assessed from chlorophyll $a$ and pheopigment concentrations. Seawater samples (250 to $500 \mathrm{~mL}$ ) were filtered on glass fiber filters (Whatman GF/F) under low vacuum and frozen at $-20{ }^{\circ} \mathrm{C}$ until analysis (within 2 months after collection). Pigments were extracted in $90 \%$ acetone overnight at $4^{\circ} \mathrm{C}$ and chlorophyll $a$, and pheopigments concentrations were estimated following Lorenzen (1966) using a pre-calibrated (chlorophyll 
$a$ from Anacystis nidulans, Sigma) fluorometer (Trilogy, Turner designs). For phytoplankton community analyses, $250 \mathrm{~mL}$ samples were preserved in the field with lugol/glutaraldehyde fixative (2 \% final concentration, Verity et al., 2007) and stored at $4{ }^{\circ} \mathrm{C}$ in the dark until analysis (within 3 months after collection). At the laboratory, 5 to $10 \mathrm{~mL}$ subsamples were settled in Hydrobios counting chambers. Phytoplankton cells were identified and enumerated using an inverted microscope (Nikon Eclipse TE2000-S, magnification ×200, ×400) under phase contrast illumination. On average $942 \pm 568$ cells per sample were identified and counted. For Phaeocystis globosa, total cells were enumerated without stage distinction (i.e. isolated, colonial stages). Under optical microscopy, Pseudo-nitzschia cells were categorized on the basis of cell width. More specifically, Pseudo-nitzschia cells with frustule width up to $3 \mu \mathrm{m}$ were placed in the $P$. delicatissima complex while those with frustules above $3 \mu \mathrm{m}$ were placed in the $P$. seriata complex as was done in several studies (Bresnan et al., 2015; Fehling et al., 2004; Hasle and Syvertsen, 1997; Thorel et al., 2017).

When Pseudo-nitzschia sp. cell concentrations were higher than $10^{3}$ cell L ${ }^{-1}$, Scanning Electron Microscopic (SEM) analyses were carried out for species identification, covering the whole study period (April 4, May 2, May 16, June 1, September 5, October 3). In short, 10 to $100 \mathrm{~mL}$ of homogenized preserved samples were filtered on polycarbonate filters $(24 \mathrm{~mm}$ diam.; $0.8 \mu \mathrm{m}$ porosity) and rinsed with Milli-Q water to eliminate salts. Filters containing diatom frustules were acid cleaned (2 - $3 \mathrm{~mL} \mathrm{HCl} \mathrm{37 \% )} \mathrm{in} \mathrm{Teflon} \mathrm{beakers} \mathrm{overnight} \mathrm{at} \mathrm{room}$ temperature and rinsed in a Milli-Q water bath. Acid and water baths were filtered once again using same filter to limit cell loss during the acidification and rinsing steps. Thereafter, filters were placed on aluminium stubs with double sticky carbon tabs and air-dried during $12 \mathrm{~h}$ under laminar flow. LAstly, dried filters were metallized under argon flow with Au/Pd during 90 s (Polaron SC 7620). Quantified measures based on literature review (e.g., valve length and width, number of fibulae and of interstriae in $10 \mu \mathrm{m}$ ) allowed for the discrimination of the 
species within Pseudo-nitzschia seriata complex (width $>3 \mu \mathrm{m}$ ) and P. delicatissima complex (width $<3 \mu \mathrm{m}$; see Table 1), but species variety could not be inferred from our study. At least 50 Pseudo-nitzschia sp. cells per sample were identified via SEM analyses. When present in lower numbers, the entire filter was scanned for Pseudo-nitzschia frustules and identification was carried out on available material. Dissolved and particulate domoic acid (DA; pg mL ${ }^{-1}$ ) concentrations were measured using ASP ELISA kits (Biosense, Bergen, Norway) following the provided procedure. Total DA concentration (tDA i.e., dissolved + particulate DA) was measured from $5 \mathrm{~mL}$ of natural seawater samples stored at $-20^{\circ} \mathrm{C}$ until analysis. For dissolved DA, collected seawater samples $(5 \mathrm{~mL})$ were filtered under low vacuum pressure ( $<50 \mathrm{~mm} \mathrm{Hg}$ ) on $0.2 \mu \mathrm{m}$ cellulose acetate filters before being frozen $(-20$ ${ }^{\circ} \mathrm{C}$ ). On the day of the analysis, samples were thawed at $4{ }^{\circ} \mathrm{C}$ and dissolved DA samples were directly processed. For total DA samples, sonication on ice was carried out in order to disrupt cells, and samples were filtered on $0.2 \mu \mathrm{m}$ cellulose acetate before the assay. Particulate DA was obtained by subtracting dissolved DA from total DA. Given the limit of Pseudo-nitzschia cell counts via microscopy, DA cell quota were computed only when Pseudo-nitzschia cell abundance reached $10^{3}$ cell L-1 (i.e. at least 5-10 Pseudo-nitzschia cells were counted).

\subsection{Data analyses}

In order to efficiently synthesize the environmental context of the survey and identify forcing parameters, a Principal Component Analysis (PCA) was applied to the environmental data matrix (11 parameters x 16 dates, Legendre and Legendre, 1998). Wind speed data from three days before the sampling date were averaged. Rainfalls were summed over 3 days before the sampling date in order to take into account watershed run-offs.

Nutrients concentrations of DIN (i.e. the sum of $\mathrm{NH}_{4}{ }^{+}, \mathrm{NO}_{2}{ }^{-}$and $\mathrm{NO}_{3}{ }^{-}$concentrations), $\mathrm{HPO}_{4}{ }^{2-}$ and $\mathrm{Si}(\mathrm{OH})_{4}$ concentrations were depicted in the PCA plots as N, P and Si, respectively. Nutrient ratios (S/P, Si/N and Si/P) were considered as illustrative variables to highlight 
potential nutrient limitations. Prior to the analysis, all data were tested for normality (Shapiro test) and $\log (\mathrm{x}+1)$ transformed.

Pseudo-nitzschia complex raw abundances were plotted on each PCA graph to give a picture of species seasonality. Only variables significantly correlated to at least one principal component (PC) of the PCA are presented and discussed (Spearman test, p-value $<0.05$ ).

Correlation coefficients will be referred to as r' ${ }_{\mathrm{PC} 1}, \mathrm{r}_{\mathrm{PC} 2}, \mathrm{r}_{\mathrm{PC} 3}$ for the first three principal components of the PCA (Table 2). Additionally, correlations between Pseudo-nitzschia complexes abundances and domoic acid concentrations have been assessed. Since data did not fit the normality, correlations were tested using Spearman test (significance threshold was set at p-value $<0.05$ ). Statistivs were performed using R software packages (R Core Team, 2012)

\section{Results}

\subsection{Environmental conditions}

The present study began in the cold snap of February 2012 (temperature of minus $10^{\circ} \mathrm{C}$ ) that had not occurred in the area since 1991 (MeteoFrance data; regional bulletin, www.meteofrance.fr). The following spring was cooler $\left(-1.0^{\circ} \mathrm{C}\right)$ and drier (half as much rainfall) than average (Figure 2A, 2C). Stormy weather dominated the summer months (JuneJuly) and autumn. Autumn 2012 was characterized by strong southwestern and northeastern winds (up to $100 \mathrm{~km} \mathrm{~h}^{-1}$ ), excess precipitations (+30\%) and a rapid drop in temperature. Seawater surface temperature followed a typical seasonal evolution increasing from $4.9^{\circ} \mathrm{C}$ in February to $19.0^{\circ} \mathrm{C}$ in August. By contrast, as measured by flood tide, salinity remained stable with an average of $34.2 \pm 0.3$ (min: 33.4, $\max =35.0$; Figure $2 \mathrm{~A}$ ). The mean annual $\mathrm{pH}$ value was $8.1 \pm 0.3$ and decreased continuously over the study period from February (8.6) to November (7.6; Figure 2B). The mean annual dissolved oxygen concentration $\left(\mathrm{dO}_{2}\right)$ was $8.1 \pm$ $1.3 \mathrm{mg} \mathrm{L}^{-1}$ with the highest values recorded in winter and late autumn , and the lowest (6.4 mg $\mathrm{L}^{-1}$ ) in late summer (Figure 2B). A slight increase in $\mathrm{dO}_{2}$ concentrations coincided with the 
spring bloom development in May. Turbidity averaged at 6.9 \pm 3.2 NTU (Figure 2C). The lowest turbidity values were measured in April and June (2.9 NTU) and the highest in May and September (14.3 and 12.1 NTU, respectively).

With the exception of $\mathrm{NH}_{4}{ }^{+}$, all concentrations of nutrients decreased rapidly to reach their annual minima of 0.01, 0.35 and $0.30 \mu \mathrm{mol} \mathrm{L}^{-1}$ for $\mathrm{NO}_{2}{ }^{-}+\mathrm{NO}_{3}{ }^{-}, \mathrm{HPO}_{4}{ }^{2-}$ and $\mathrm{Si}(\mathrm{OH})_{4}$, respectively, in April (Figure 3). Thereafter, $\mathrm{HPO}_{4}{ }^{2-}$ concentration varied between 0.5 and 1.0 $\mu \mathrm{mol} \mathrm{L}{ }^{-1}$ and the maximal values followed storm events (July and November). $\mathrm{NO}_{2}{ }^{-}+\mathrm{NO}_{3}{ }^{-}$ concentrations remained stable below $5 \mu \mathrm{mol} \mathrm{L}{ }^{-1}$ from April to October and increased to high values at the end of the survey $\left(11.7 \mu \mathrm{mol} \mathrm{L}^{-1}\right)$ although they did not reach the previous winter maxima of $22.5 \mu \mathrm{mol} \mathrm{L}{ }^{-1}$. Silicate concentrations decreased from 7.5 to 0.3 between February and late March. A second minimal value $\left(0.2 \mu \mathrm{mol} \mathrm{L}{ }^{-1}\right)$ was recorded in June. The silicate concentrations increased continuously during summer and reached $7.5 \mu \mathrm{mol} \mathrm{L} \mathrm{L}^{-1}$ at the end of the survey. $\mathrm{NH}_{4}{ }^{+}$concentrations were highly variable from February to June ranging between 1.0 and $3.8 \mu \mathrm{mol} \mathrm{L}{ }^{-1}$. Thereafter, concentrations remained between 2.0 to $4.0 \mu \mathrm{mol} \mathrm{L}{ }^{-1}$.

\subsection{Phytoplankton standing stock, seasonality and domoic acid levels}

The phytoplankton bloom, started at the end of February 2012 and lasted until early June. It was characterized by three successive peaks in chlorophyll $a$ concentrations (from 4.0 to 9.5 $\mu \mathrm{g}$ chla $\mathrm{L}^{-1}$; Figure $4 \mathrm{~A}$ ), and phytoplankton abundance (from $8.2 \times 10^{5}$ to $3.6 \times 10^{6}$ cells $\mathrm{L}^{-1}$; Figure 4B). From July to November, chlorophyll $a$ concentrations $\left(2.3 \pm 0.7 \mu \mathrm{g} \mathrm{L}^{-1}\right)$ along with phytoplankton abundance $\left(1.9 \pm 0.7 \times 10^{5}\right.$ cells $\left.\mathrm{L}^{-1}\right)$ remained relatively stable and low. Pheopigment concentrations followed the same pattern as chlorophyll $a$ (Figure 5A) and represented 22 to $49 \%$ of total pigments. Four periods could be identified based on phytoplankton community composition (Figure 4C): Period 1 (P1, February 20 - April 5) was characterized by the dominance of small diatoms (5-20 $\mu \mathrm{m}$ in width/length; Thalassiosira sp., Skeletonema costatum, Asterionellopsis glacialis and Chaetoceros sp.), either as isolated cells 
or in forming colonies, and phytoplankton abundance peaked at $8.2 \times 10^{5}$ cells $\mathrm{L}^{-1}$. Period 2 (P2, April 5 to May 20) corresponded to the P. globosa bloom with abundances ranging from 1.8 to $3.6 \times 10^{6}$ cells $\mathrm{L}^{-1}$ (Figure 4B). This bloom co-occurred with high abundances of Chaetoceros sp. $\left(8.7 \times 10^{4}\right.$ cells $\mathrm{L}^{-1}, 64 \%$ of the diatom community at the beginning of P2), and Pseudo-nitzschia sp. $\left(2.1 \times 10^{5}\right.$ cells $\mathrm{L}^{-1}$ equivalent to $25 \%$ and $86 \%$ of the phytoplankton and the diatom communities, respectively; at the end of P2). Period 3 is the post-bloom period (P3, from May 20 to September 8). Both fine walled summer diatoms such as Guinardia sp. (i.e. G. delicatula, G. flaccida, and G. striata), and highly silicified spring diatoms such as Chaetoceros sp. and Thalassiosira sp. composed the bulk of the diatom community in association with small Cryptophytes. Period 4 (P4, from September 8 to November 16) revealed the occurrence of intermediate sized diatoms (30 - $40 \mu \mathrm{m}$ in length/width; Delphineis sp.) as well as diatoms in forming colonies (e.g., Thalassiosira sp.) which remained in low number $\left(1.2 \pm 0.5 \times 10^{5}\right.$ cells $\left.L^{-1}\right)$.

SEM analyses revealed a low diversity of Pseudo-nitzschia sp. in the area with three distinct species namely $P$. delicatissima (belonging to the $P$. delicatissima complex), $P$. fraudulenta, and $P$. pungens (both belonging to the P. seriata complex, see Table 1 and Figure 5). No overlap between the two complexes was found in terms of species morphological features since the width of $P$. delicatissima width was below $2 \mu \mathrm{m}$, and the widths of $P$. pungens and $P$. seriata were above $2.7 \mu \mathrm{m}$ (Table 1). $P$. delicatissima represented up to $99 \%$ of SEMidentified frustules during the P. globosa bloom period (P2, Mid-May) and outnumbered other diatoms. By contrast, at the beginning of the post-bloom period (P3), the percentage of Pseudo-nitzschia sp. to total diatoms decreased to $10 \%$ of total diatoms. P. pungens markedly dominated (54 \% of the SEM-identified frustules) over P. fraudulenta and P. delicatissima (33\% and $13 \%$, respectively). In autumn (P4), all the identified Pseudo-nitzschia sp. 
237 frustules belonged to the $P$. pungens species $\left(<10^{3}\right.$ cells $\mathrm{L}^{-1}$ representing $<1 \%$ of total 238 diatoms).

239 Domoic acid was mostly present as dissolved DA throughout the survey averaging $83 \pm 16 \%$ 240 of the total DA (tDA). Particulate domoic acid (pDA) was detected in May (end of P2) and 241 was still measurable at the end of P4. pDA punctually represented 10 to $40 \%$ of tDA (Figure 242 6). tDA concentration followed Pseudo-nitzschia sp. dynamics, particularly during the $P$. 243 globosa bloom and post-bloom periods (P2 and P3, Figure 7). tDA maxima (263 pg mL ${ }^{-1}$ ) corresponded to the co-occurrence of $P$. seriata complex and P. delicatissima complex, reaching $2.8 \times 10^{4}$ and $7.5 \times 10^{5}$ cells $\mathrm{L}^{-1}$ in early May (P2), respectively. Thereafter, tDA decreased to 118 and $110 \mathrm{pg} \mathrm{mL}^{-1}$ at the end of P2 and beginning of P3, which coincided with the highest abundance of $P$. delicatissima complex and $P$. seriata complex, respectively. In autumn, tDA concentrations remained high $\left(102 \pm 39 \mathrm{pg} \mathrm{mL}^{-1}\right)$ despite low abundances of $P$. seriata complex (i.e. P. pungens), as suggested by the absence of correlation between tDA and Pseudo-nitzschia abundances. When measurable, DA cell quota ranged between 0.016 pg cell $^{-1}$ in May and 7.9 pg cell $^{-1}$ in September.

\subsection{Abundance of Pseudo-nitzschia in relation to environmental factors}

PCA confirmed the clear seasonal pattern of environmental variables and allowed to synthesize their relation with the temporal variability of Pseudo-nitzschia (Figure 7). The first three principal components (PC) explained $75.82 \%$ of the total variance (PC1: $35.01 \%$, PC2: 28.77 \%, PC3: $12.04 \%)$. Considering coefficients in the linear combination of variables, period P1 was mainly characterized by high DIN $\left(\mathrm{r}^{\prime}{ }_{\mathrm{PC} 1}=0.88\right)$ and $\mathrm{dO}_{2}\left(\mathrm{r}^{\prime}{ }_{\mathrm{PC} 2}=-0.75\right)$ concentrations, high N/P ratios ( $\left.{ }^{\prime}{ }_{\mathrm{PC} 1}=0.66 ; \mathrm{r}_{\mathrm{PC} 2}=-0.50\right)$ and low temperature and salinity

259 (r’ ${ }^{\prime}{ }_{2}=0.73$ and 0.64 , respectively; Table 2). P2 (bloom period) was more related to high ssi 260 (r'PC1 =-0.74), $\mathrm{pH}\left(\mathrm{r}^{\prime}{ }_{\mathrm{PC} 2}=-0.64\right)$, and increases in temperature and salinity ( $\mathrm{r}_{\mathrm{PC} 2}=0.73$ and 
lesser extent low Si/P ratio (r'PC2 $=0.44$, Table 2). Additionally, punctual storm events in May characterized by high rainfalls ( $\left.\mathrm{r}_{\mathrm{PC} 3}=0.61\right)$ and by strong winds $\left(\mathrm{r}^{\prime}{ }_{\mathrm{PC} 3}=0.43\right)$ led to a prompt increase in turbidity (Figures 3 and 7B). High temperature, DIN limitations illustrated by low N/P, and increasing Si/P ratio and $\mathrm{Si}(\mathrm{OH})_{4}$ concentrations characterized periods $\mathrm{P} 3$ and $\mathrm{P} 4$ (Table 2).

The plotting of Pseudo-nitzschia abundance on the PCA graphs illustrated the importance of high rainfall, increasing $\mathrm{pH}$, ssi in the initiation of the $P$. delicatissima complex bloom (Figures 7A and 7B). The seasonality of the $P$. seriata complex was essentially shown by their high abundance in June (beginning of P3) and their disappearance in August and September (end of P3; Figures 7C and 7D). The highest abundance of P. seriata complex was observed at low nutrient levels (particularly DIN and $\left.\mathrm{Si}(\mathrm{OH})_{4}\right)$, increasing surface solar irradiance and high pH. From September to November 2012 (P4), rainfalls and wind speed decreased, and $P$. seriata complex persisted at low abundance in increasing concentrations of $\mathrm{Si}(\mathrm{OH})_{4}$, decreasing $\mathrm{pH}$ and concentrations of $\mathrm{dO}_{2}$. Finally, as illustrated by the distribution of abundance values on the PCA plots, both complexes were present under $\mathrm{Si}(\mathrm{OH})_{4}$ limitation and the $P$. seriata complex seemed to tolerate higher variable environmental conditions (e.g. nutrients) as compared to the $P$. delicatissima complex.

\section{Discussion}

\subsection{Specificity of the 2012 spring bloom}

In the southern North Sea - Eastern English Channel ecosystem, the phenology of phytoplankton communities is generally characterized by a phytoplankton spring bloom dominated by Phaeocystis globosa (Gentilhomme and Lizon, 1998; Lefebvre et al., 2011; Schapira et al., 2008). In 2012, the spring bloom appeared to be of low magnitude and short duration compared to other studies ( $20 \mu \mathrm{g} \mathrm{L}^{-1}$ in Breton et al., 2000 and Kesaulya et al., 2008 ; $50 \mu \mathrm{g} \mathrm{L}^{-1}$ in Lefebvre et al., 2011; Seuront et al., 2006), as exemplified by low 
chlorophyll $a$ values (9.5 $\mu \mathrm{g} \mathrm{L} \mathrm{L}^{-1}$, Figure 4A). This small bloom magnitude was confirmed by the low P. globosa abundance (between 0.019 and $3.7 \times 10^{6}$ cell $\mathrm{L}^{-1}$ in this study vs 5.5 to $100 \times 10^{6}$ cell L ${ }^{-1}$ in Gómez and Souissi, 2008; Seuront et al., 2006; Widdicombe et al., 2010) and its low contribution to total phytoplankton abundance (50 \% vs 74-90\% between 1992 and 2011, Hernández-Fariñas et al., 2014). P. globosa dynamics can exhibit high interannual variability (Lamy et al., 2006; Lefebvre et al., 2011) and the year 2012 appeared as a low Phaeocystis year. The co-occurrence of the P. delicatissima complex and P. globosa development (Figure 4; Period P2) is often described: P. delicatissima complex is a cooccurring species of P. globosa bloom (Grattepanche et al., 2011; Hernández-Fariñas et al., 2014; Monchy et al., 2012; Sazhin et al., 2007) and may serve as solid substrate during the transitional phase from free-living cells to colonial stages (Peperzak and Gäbler-Schwarz, 2012; Rousseau et al., 2007; Verity et al., 2007).

4.2 Environmental factors drive Pseudo-nitzschia diversity and seasonality. Three species of Pseudo-nitzschia were identified in 2012 in the Southern North Sea $(P$. delicatissima, $P$. pungens and $P$. fraudulenta) by using SEM imagery and measurements. These results are congruent with recent published data from adjacent areas (Eastern English Channel - Thorel et al., 2017, Northern North Sea - Bresnan et al., 2015). Identification was based on a literature review and best matches with species morphometric issues are specified in Table 1. The identification of Pseudo-nitzschia species is a tricky issue since some species can have very similar morphological characteristics (e.g. P. delicatissima with $P$. dolorosa, $P$. decipiens or P. fraudulenta with P. subfraudulenta, Amato et al., 2007; Orsini et al., 2004; Quijano-Scheggia et al., 2009). Further studies are therefore needed to confirm these identifications using molecular tools (e.g. Pugliese et al. 2017). The seasonality of Pseudo-nitzschia species within the Eastern English Channel - North Sea (EEC-NS) ecosystem resulted in two distinct periods of abundance (spring and autumn) 
during which a very small number of Pseudo-nitzschia species was observed. The three identified species (P. delicatissima, $P$. pungens, and $P$. fraudulenta) are considered to be cosmopolites (see Table 3; Hasle 2002 and Lelong et al. 2012 for reviews). They are also known to have different but variable hydrological preferences depending on their ecosystem inhabited, and genetic strains. Temperature and salinity values recorded in $2012\left(4.9-19.0^{\circ} \mathrm{C}\right.$ and 33.6-35.0, respectively; Figure 2A) are consistent with the euryhaline features of Pseudonitzschia spp. Most species are indeed able to grow at salinities comprised between 1 and > 30, occurring and growing more efficiently at high salinity (Cho et al., 2001; Husson et al., 2016; Thessen et al., 2005). Prior studies have also demonstrated a wide temperature range for Pseudo-nitzschia spp. (Dortch et al., 1997; Louw et al., 2016; Tas and Lundholm, 2016). In particular, $P$. delicatissima, which was dominant in May (P2, 86\% of the diatom community and $99 \%$ of identified frustules) seemed to better grow at temperatures ranging between 10$12{ }^{\circ} \mathrm{C}$ (Table 3; Fehling et al. 2006). P. pungens and $P$. fraudulenta were commonly present in summer (June) and autumn (October) when days were longer and temperatures higher (Table 3). However, $P$. pungens seems to have a wider environmental tolerance than $P$. fraudulenta (Klein et al., 2010) as it can peak at temperatures up to $21.0^{\circ} \mathrm{C}$ (Terenko and Terenko, 2012). The increasing relative contribution of P. pungens to Pseudo-nitzschia species between June (54 \%) and October (100 \%) may be explained by two non-conflicting hypotheses. Firstly, the P. pungens population may comprise different varieties exhibiting different temperature preferences (e.g. Kim et al. 2015). Secondly, it can present varying responses to temperature increases (Thessen et al., 2009). P. delicatissima development began in February (P1) under high DIN concentrations, high N/P ratios and low temperature (i.e. late winter conditions; Figure 7A, 7B). It is well known that high abundances of Pseudo-nitzschia spp. are found in areas enriched with nutrients (Parsons et al., 2002; Tas et al., 2016) which can originate from upwelling (Díaz et al., 2014), 
mixing events and riverine inputs (Trainer et al., 2012). Paradoxically, the highest abundance of $P$. delicatissima in May (P2) occurred after a decrease in DIN concentrations and rather suggested nutrient limiting conditions. Pulses of DIN (Figure 3A) following rainfall events in May (Figure 2C) could have favored the species rapid growth and bloom, a phenomenon which has already been shown in estuarine systems (Tas et al., 2016; Tas and Lundholm, 2016). The results of this study also demonstrated that the maximum abundance of the $P$. delicatissima complex e occurred at high $\mathrm{pH}$ levels and $\mathrm{dO}_{2}$ concentrations (P2, Figure 7). Lundholm et al. (2004) suggested that high pH values (8.7 - 9.1) can inhibit the growth of most Pseudo-nitzschia species. Such high values were never recorded during our study (7.6 to 8.6; Figure 3) and no significant relationships could be established between $\mathrm{pH}$ values and Pseudo-nitzschia abundance. Rather than being associated solely with the P. delicatissima complex, variability in $\mathrm{dO}_{2}$ is likely associated with the photosynthetic activity of the whole phytoplankton community including the Phaeocystis sp. bloom (P2).

High amount of particulate matter (i.e., high turbidity) linked to water mixing and river inputs can limit light availability and consequently inhibit photosynthesis and growth. This light attenuation can result in the limitation of both the spatial and temporal distribution of Pseudonitzschia as demonstrated in estuarine and coastal systems (Dursun et al., 2016; Tas et al., 2016). These studies are consistent with the $P$. seriata complex distribution pattern in the Southern Bight of the North Sea (SBNS), the species being abundant when turbidity was low (e.g. in June, Figure 2C, 7D). P. delicatissima could have benefited from the storm event (high wind and rainfall) which occurred in May and particularly from the subsequent pulses of DIN and $\mathrm{Si}(\mathrm{OH})_{4}$ (Figures $3 \mathrm{~A}$ and $\left.7 \mathrm{~B}\right)$.

The $P$. seriata species complex was the most abundant (beginning of P3) in low DIN and $\mathrm{SiOH}_{4}$ concentrations resulting in low $\mathrm{Si} / \mathrm{N}$ ratios (figure 7C). These conditions may have been caused by the lag effect of P. delicatissima and the associated P. globosa bloom having 
already drawn down the nutrients. The $P$. seriata species complex was still persisting at low abundance in the area from the end of the summer to the fall (end of P3 and P4). PCA plots suggest that the growth of the $P$. seriata complex may benefit from nutrient pulses of silicate, phosphate and DIN but that it tends to be limited at that time of the year by decreasing temperature and irradiance (Figure 7C, 7D).

Silicate limitations were already proven to increase Pseudo-nitzschia abundance and toxicity (Anderson et al., 2010; Thorel et al., 2017). For instance, $P$. multiseries was able to outcompete other phytoplankton species when silicate was low compared to nitrogen (Sommer, 1994). Laboratory culture conditions conducive to DA production generally include limitation by silicate or phosphate during the stationary phase (reviewed by Bates et al., 1989; Trainer et al., 2012, 2008). This could explain this study findings of the high domoic acid concentration in spring (P2, May, Figure 6) which coincided with low Si and DIN concentrations along with low Si/P ratios (Figure 7A- C). However, no significant correlation could be demonstrated between nutrients stocks and DA concentrations. Consequently, more targeted studies (e.g., nutrient uptake experiments) are required in order to properly evaluate the nitrogen nutritional status and nitrogen preference (i.e., $\mathrm{NO}_{2}{ }^{-}+\mathrm{NO}_{3}{ }^{-} \mathrm{vs} \mathrm{NH}_{4}{ }^{+}$vs urea) for Pseudo-nitzschia populations, and thus the potential influence of nitrogen on bloom dynamics and toxicity in the EEC-NS.

\subsection{Domoic acid concentrations and Pseudo-nitzschia species}

The existence of toxigenic and non-toxigenic strains of the same species has been mentioned recurrently for several Pseudo-nitzschia species (e.g. Sahraoui et al. 2011; Thessen et al. 2009; Villac et al. 1993)Sahraoui et al., 2011; Thessen et al., 2009; Villac et al., 1993). Total DA concentrations measured during this study (max. $263 \mathrm{pg} \mathrm{mL}^{-1}$ ) were higher than several published values in the EEC-NS ecosystem (up to $7 \mathrm{pg} \mathrm{mL}^{-1}$; Downes-Tettmar et al. 2013; Klein et al. 2010) but remained lower than recent measurements in the Bay of Seine $\left(1.4 \times 10^{3}\right.$ 
pg $\mathrm{mL}^{-1}$, Thorel et al. 2017), and other ecosystems such as Monterey Bay $\left(10 \times 10^{3} \mathrm{pg} \mathrm{mL}^{-1}\right.$; Walz et al. 1994), the Gulf of Mexico (3.3×10 $\mathrm{pg} \mathrm{mL}^{-1}$, Liefer et al. 2013) or Luanda Bay,

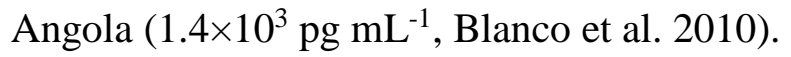

Although Pseudo-nitzschia abundance matched high DA concentration in spring, this observation did not hold for the end of summer and autumn periods (Figure 6). Other species (i.e. Nitzschia navis-vargnica and $N$. bizertensis) are known to produce DA in south-east Asia and Tunisia, respectively (Bouchouicha-Smida et al., 2015; Kotaki et al., 2000; Lundholm and Moestrup, 2000; Tan et al., 2016). Since neither species has been detected in North Atlantic waters (including the English Channel and the North Sea) or been observed during this 2012 survey, it is likely that DA originate exclusively from Pseudo-nitzschia species.

Consequently, this result supports other studies where DA concentration in seawater (particulate and dissolved) or in shellfish does not always depend on Pseudo-nitzschia abundance (e.g. Bates et al. 1998; Bresnan et al. 2017; Klein et al. 2010; Lelong et al. 2012; Walz et al. 1994). During P2 and P3, high tDA concentrations coincided with the cooccurrence of two or three Pseudo-nitzschia species (i.e., P. delicatissima and P. pungens during $\mathrm{P} 2$ and $P$. delicatissima, $P$. pungens and $P$. fraudulenta during P3). Since these three species have been proven at least once to produce DA (Lelong et al., 2012), the formal identification of the species responsible for DA concentration cannot be addressed with certainty. Consistent with Downes-Tettmar et al. (2013), P. pungens was certainly toxic as it was the only Pseudo-nitzschia sp. present in autumn when DA concentrations reached 101 pg $\mathrm{mL}^{-1}$. P. delicatissima and $P$. fraudulenta were demonstrated to be weakly toxigenic in different ecosystems (Almandoz et al., 2017; Parsons et al., 2012; Rhodes et al., 1998). Additionally, in the northern North Sea, $P$. delicatissima cells have not been observed to produce DA (Scottish Waters, (Fehling et al., 2006, 2004). The DA cell quotas estimated for the three samples in which particulate DA was associated with Pseudo-nitzschia abundance > 
$10^{3}$ cell $\mathrm{L}^{-1}$ ranged between 0.016 and $7.9 \mathrm{pg}$. cell ${ }^{-1}$. These DA cell quotas are comparable to values obtained for batch cultures of P. fraudulenta (0.03 pg.cell ${ }^{-1}$, Rhodes et al. 1998; 0.16 pg.cell ${ }^{-1}$, Thessen et al. 2009) and $P$. pungens (0.2 to 10 pg. cell ${ }^{-1}$; Lelong et al. 2012). They are also congruent with DA cell quotas inferred from in situ surveys for $P$. fraudulenta $(0.002$ to 0.120 pg. cell ${ }^{-1}$; Almandoz et al. 2017) and P. delicatissima (1.52 to 5.54 pg. cell $^{-1}$, Parsons et al. 2012).

4.4 DA implications in the ecosystem and challenges for future surveys In this study, the high proportion of dissolved domoic acid year round ( 83\%) may have two main implications regarding phytoplankton communities succession and marine resources.

Dissolved domoic acid can indeed act as an effective Fe chelator, increasing its bioavailability and providing a competitive advantage to Pseudo-nitzschia sp. over other phytoplankton species for Fe assimilation (Prince et al., 2013; Rue and Bruland, 2001; Trick et al., 2010; Zabaglo et al., 2016). Other studies suggest that DA synthesis requires available Fe (e.g. Sobrinho et al. 2017). In both cases, accumulated iron in the polysaccharidic matrix of $P$. globosa (Schoemann et al., 2005) could have benefitted Pseudo-nitzschia sp. growth and DA production and could well explain its appearance every year, during and after the P. globosa bloom.

Regarding marine resources, dissolved DA is reported to alter bivalve larvae growth (Liu et al., 2007) and immunity (De Rijcke et al., 2015) and these effects could spread to population recruitment and picking activities. Dissolved DA is also reported to inhibit herbivorous feeding as shown for krill (Bargu et al., 2006) and copepod species (Tammilehto et al., 2015) modifying matter and energy fluxes within the trophic web. These elements suggest the potential for dissolved DA to impact marine resources throughout the year and to trigger longterm effects regarding growth and recruitment. 
Despite its absence in spring, particulate DA appeared at significant level (10-40\%) over a wide temporal window (May to December). During this period, Pseudo-nitzschia sp. could provide a non-negligible food source from which particulate DA could be directly transferred to higher trophic levels such as exploited filter feeders namely mussels or king scallops in the EEC-NS (Ambiaud and Lefebvre, 2017). Phytoplankton consumers such as Noctiluca scintillans and copepods could act as DA vectors/inducers (Escalera et al., 2007; Fock and Greve, 2002; Leandro et al., 2010; Maneiro et al., 2005; Tammilehto et al., 2015) and were shown to dominate the zooplankton community when particulate DA reached $40 \%$ of total DA in the summer. Our data suggest that the SBNS could be an at-risk area regarding DA contamination and/or exposure of marine resources to dissolved DA: the phytoplankton abundance alert threshold was reached at least once for the $P$. delicatissima complex during the 2012 survey (i.e. >300 000 cells L ${ }^{-1}$, (EC) No 853/2004 2004; (EC) No 854/2004 2004) concomitantly with significant DA concentrations in seawater. However, high domoic acid concentration was not always associated with high Pseudo-nitzschia abundance. This study at the seasonal scale allowed the identification of risky periods regarding species diversity and DA forms and concentrations in the SBNS ecosystem. Given the inter-annual variability of Pseudo-nitzschia species occurrence (e.g. Thorel et al. 2017), long term monitoring is fundamental to assess whether the species seasonality persist over years and whether it is always associated to the same toxigenic species and environmental parameters.

\section{Acknowledgments}

We acknowledge J. Mestre, B. Gomez and T. Raud for their technical support in the field and at the laboratory. A PhD grant from the région Nord Pas-de-Calais and the Syndicat Mixte de la Côte d'Opale (SMCO) attributed to A. Delegrange supported this work. This work was also funded by a collaborative convention between former Aquanord S.A. and ULCO/LOG. We thank Dr. Hélène Hégaret and Dr. Philippe Soudant (IUEM - LEMAR) for relevant comments 
and constructive suggestions on a former version of this manuscript. We also thank two

462

463

464

465

466

467

468

469

470

471

472

473

474

475

476

477

478

479

480

481

482

483

484

485

486

487

488

489

490

491

492

493

494

495

496

497

498

499

500

501

502

503

504

505

anonymous reviewers for their comments and suggestions improving our data presentation

and species description. Thanks are also due to Jennifer Morival

(jennifermorival.wixsite.com) for the complete English edition and correction of the

manuscript.

\section{References}

Almandoz, G.O., Fabro, E., Ferrario, M., Tillmann, U., Cembella, A., Krock, B., 2017. Species occurrence of the potentially toxigenic diatom genus Pseudo-nitzschia and the associated neurotoxin domoic acid in the Argentine Sea. Harmful Algae 63, 45-55. https://doi.org/10.1016/j.hal.2017.01.007

Amato, A., Kooistra, W.H.C.F., Levialdi Ghiron, J.H., Mann, D.G., Pröschold, T., Montresor, M., 2007. Reproductive Isolation among Sympatric Cryptic Species in Marine Diatoms. Protist 158, 193207. https://doi.org/10.1016/j.protis.2006.10.001

Anderson, C.R., Sapiano, M.R.P., Prasad, M.B.K., Long, W., Tango, P.J., Brown, C.W., Murtugudde, R., 2010. Predicting potentially toxigenic Pseudo-nitzschia blooms in the Chesapeake Bay. J. Mar. Syst., GEOHAB Modeling 83, 127-140. https://doi.org/10.1016/j.jmarsys.2010.04.003

Bargu, S., Lefebvre, K., Silver, M.W., 2006. Effect of dissolved domoic acid on the grazing rate of krill Euphausia pacifica. Mar. Ecol. Prog. Ser. 312, 169-175. https://doi.org/10.2307/24870068

Bates, S.S., Bird, C.J., de Freitas, A.S.W., Foxall, R., Gilgan, M., Hanic, L.A., Johnson, G.R., McCulloch, A.W., Odense, P., Pocklington, R., Quilliam, M.A., Sim, P.G., Smith, J.C., Subba Rao, D.V., Todd, E.C.D., Walter, J.A., Wright, J.L.C., 1989. Pennate diatom Nitzschia pungens as the primary source of domoic acid, a toxin in shellfish from eastern Prince Edward Island, Canada. Can Fish Aquat Sci 1203-1215.

Bates, S.S., Garrison, D.L., Horner, R.A., 1998. Bloom Dynamics and Physiology of Domoic-AcidProducing Pseudo-nitzschia Species, in: Physiological Ecology of Harmful Algal Blooms. Anderson, D.M., Cembella A.D., and Hallegraeff G.M., Heidelberg, pp. 267-292.

Bendschneider, K., Robinson, R.J., 1952. A New Spectrophotometric Method for the Determination of Nitrite in Sea Water.

Blanco, J., Livramento, F., Rangel, I.M., 2010. Amnesic shellfish poisoning (ASP) toxins in plankton and molluscs from Luanda Bay, Angola. Toxicon 55, 541-546. https://doi.org/10.1016/j.toxicon.2009.10.008

Bonato, S., Christaki, U., Lefebvre, A., Lizon, F., Thyssen, M., Artigas, L.F., 2015. High spatial variability of phytoplankton assessed by flow cytometry, in a dynamic productive coastal area, in spring: The eastern English Channel. Estuar. Coast. Shelf Sci. 154, 214-223. https://doi.org/10.1016/j.ecss.2014.12.037

Bouchouicha-Smida, D., Bates, S.S., Lundholm, N., Lambert, C., Mabrouk, H.H., Sakka Hlaili, A., 2015. Viability, growth and domoic acid toxicity of the diatom Nitzschia bizertensis following filtration by the mussel Mytilus sp. Mar. Biol. 162, 0. https://doi.org/10.1007/s00227-0152758-x

Bresnan, E., Fryer, R.J., Fraser, S., Smith, N., Stobo, L., Brown, N., Turrell, E., 2017. The relationship between Pseudo-nitzschia (Peragallo) and domoic acid in Scottish shellfish. Harmful Algae 63, 193-202. https://doi.org/10.1016/j.hal.2017.01.004

Bresnan, E., Kraberg, A., Fraser, S., Brown, L., Hughes, S., Wiltshire, K.H., 2015. Diversity and seasonality of Pseudo-nitzschia (Peragallo) at two North Sea time-series monitoring sites. Helgol. Mar. Res. 1-12. https://doi.org/10.1007/s10152-015-0428-5 
Breton, E., Brunet, C., Sautour, B., Brylinski, J.-M., 2000. Annual variations of phytoplankton biomass in the Eastern English Channel: comparison by pigment signatures and microscopic counts. J. Plankton Res. 22, 1423-1440. https://doi.org/10.1093/plankt/22.8.1423

Brown, L., Bresnan, E., 2008. Seasonal occurrence of Pseudo-nitzschia species in the west coast and Shetland Isles, Scotland, in: Proceedings of the 12th International Conference on Harmful Algae. Presented at the 12th International Conference on Harmful Algae, Moestrup, $\varnothing$. et al., Copenhagen, Denmark, pp. 165-167.

Cho, E.S., Park, J.G., Oh, B.C., Cho, Y.C., 2001. The application of species specific DNA-targeted probes and fluorescently tagged lectin to differentiate several species of Pseudo-nitzschia (Bacillophyceae) in Chinhae Bay, Korea. Sci. Mar. 65, 207-214.

De Rijcke, M., Vandegehuchte, M.B., Vanden Bussche, J., Nevejan, N., Vanhaecke, L., De Schamphelaere, K.A.C., Janssen, C.R., 2015. Common European harmful algal blooms affect the viability and innate immune responses of Mytilus edulis larvae - ScienceDirect. Fish Shellfish Immunol. 47, 175-181. https://doi.org/10.1016/j.fsi.2015.09.003

Díaz, P.A., Ruiz-Villarreal, M., Velo-Suárez, L., Ramilo, I., Gentien, P., Lunven, M., Fernand, L., Raine, R., Reguera, B., 2014. Tidal and wind-event variability and the distribution of two groups of Pseudo-nitzschia species in an upwelling-influenced Ría. Deep Sea Res. Part II Top. Stud. Oceanogr., Harmful Algal Blooms in Stratified Systems 101, 163-179. https://doi.org/10.1016/j.dsr2.2013.09.043

Dortch, Q., Robichaux, R., Pool, S., Milsted, D., Mire, G., Rabalais, N., Soniat, T., Fryxell, G., Turner, R., Parsons, M., 1997. Abundance and vertical flux of Pseudo-nitzschia in the northern Gulf of Mexico. Mar. Ecol. Prog. Ser. 146, 249-264. https://doi.org/10.3354/meps146249

Downes-Tettmar, N., Rowland, S., Widdicombe, C., Woodward, M., Llewellyn, C., 2013. Seasonal variation in Pseudo-nitzschia spp. and domoic acid in the Western English Channel. Cont. Shelf Res. 53, 40-49. https://doi.org/10.1016/j.csr.2012.10.011

Du, X., Peterson, W., Fisher, J., Hunter, M., Peterson, J., 2016. Initiation and Development of a Toxic and Persistent Pseudo-nitzschia Bloom off the Oregon Coast in Spring/Summer 2015. PLOS ONE 11, e0163977. https://doi.org/10.1371/journal.pone.0163977

Dursun, F., Yurdun, T., Ünlü, S., 2016. The First Observation of Domoic Acid in Plankton Net Samples from the Sea of Marmara, Turkey. Bull. Environ. Contam. Toxicol. 96, 70-75. https://doi.org/10.1007/s00128-015-1704-4

(EC) No 853/2004, 2004. Regulation (EC) No 853/2004 of the European parliament and of the council og 29 April 2004 laying down specific hygiene rules for on the hygiene of foodstuffs. Off. J. Eur. Union 47.

(EC) No 854/2004, 2004. Regulation (EC) No 854/2004 of the European parliament and of the council og 29 April 2004 laying down specific rules for the organization of official controls on products of animal origin intended for human consumption. Off. J. Eur. Union 47.

Escalera, L., Pazos, Y., Moroño, Á., Reguera, B., 2007. Noctiluca scintillans may act as a vector of toxigenic microalgae. Harmful Algae 6, 317-320. https://doi.org/10.1016/j.hal.2006.04.006

Fehling, J., Davidson, K., Bolch, C., Tett, P., 2006. Seasonality of Pseudo-nitzschia spp.(Bacillariophyceae) in western Scottish waters. Mar. Ecol. Prog. Ser. 323, 91-105.

Fehling, J., Green, D.H., Davidson, K., Bolch, C.J., Bates, S.S., 2004. Domoic acid production by Pseudo-nitzschia seriata (Bacillariophyceae) in Scottish waters. J. Phycol. 40, 622-630. https://doi.org/10.1111/j.1529-8817.2004.03200.x

Fock, H., Greve, W., 2002. Analysis and interpretation of recurrent spatio-temporal patterns in zooplankton dynamics: a case study on Noctiluca scintillans (Dinophyceae) in the German Bight (North Sea). Mar. Biol. 140, 59-73. https://doi.org/10.1007/s002270100685

Gai, F.F., Hedemand, C.K., Louw, D.C., Grobler, K., Krock, B., Moestrup, Ø., Lundholm, N., 2018. Morphological, molecular and toxigenic characteristics of Namibian Pseudo-nitzschia species - including Pseudo-nitzschia bucculenta sp. nov. Harmful Algae 76, 80-95. https://doi.org/10.1016/j.hal.2018.05.003 
Gentilhomme, V., Lizon, F., 1998. Seasonal cycle of nitrogen and phytoplankton biomass in a wellmixed coastal system (Eastern English Channel). Hydrobiologia 361, 191-199. https://doi.org/10.1023/A:1003134617808

Gibble, C., Duerr, R., Bodenstein, B., Lindquist, K., Lindsey, J., Beck, J., Henkel, L., Roletto, J., Harvey, J., Kudela, R., 2018. Investigation of a Largescale Common Murre (Uria aalge) Mortality Event in California, USA, in 2015. J. Wildl. Dis. 54, 569-574. https://doi.org/10.7589/2017-07-179

Gómez, F., Souissi, S., 2008. The impact of the 2003 summer heat wave and the 2005 late cold wave on the phytoplankton in the north-eastern English Channel. C. R. Biol. 331, 678-685. https://doi.org/10.1016/j.crvi.2008.06.005

Grattepanche, J.-D., Breton, E., Brylinski, J.-M., Lecuyer, E., Christaki, U., 2011. Succession of primary producers and micrograzers in a coastal ecosystem dominated by Phaeocystis globosa blooms. J. Plankton Res. 33, 37-50. https://doi.org/10.1093/plankt/fbq097

Hasle, G.R., 2002. Are most of the domoic acid-producing species of the diatom genus Pseudonitzschia cosmopolites? Harmful Algae 1, 137-146. https://doi.org/10.1016/S15689883(02)00014-8

Hasle, G.R., Syvertsen, E.E., 1997. Marine diatoms, in: Identifying Marine Phytoplankton. Tomas C.R., pp. 5-385.

Hernández-Fariñas, T., Soudant, D., Barillé, L., Belin, C., Lefebvre, A., Bacher, C., 2014. Temporal changes in the phytoplankton community along the French coast of the eastern English Channel and the southern Bight of the North Sea. ICES J. Mar. Sci. 71, 821-833. https://doi.org/10.1093/icesjms/fst192

Holmes, Aminot, A., Kerouel, R., Hooker, B.A., Peterson, B.J., 1999. A simple and precise method for measuring ammonium in marine and freshwater ecosystems. Can. J. Fish. Aquat. Sci. 56, 1801-1808.

Husson, B., Hernández-Fariñas, T., Le Gendre, R., Schapira, M., Chapelle, A., 2016. Two decades of Pseudo-nitzschia spp. blooms and king scallop (Pecten maximus) contamination by domoic acid along the French Atlantic and English Channel coasts: Seasonal dynamics, spatial heterogeneity and interannual variability. Harmful Algae 51, 26-39. https://doi.org/10.1016/j.hal.2015.10.017

Jensen, S.-K., Lacaze, J.-P., Hermann, G., Kershaw, J., Brownlow, A., Turner, A., Hall, A., 2015. Detection and effects of harmful algal toxins in Scottish harbour seals and potential links to population decline. Toxicon 97, 1-14. https://doi.org/10.1016/j.toxicon.2015.02.002

Kesaulya, I., Leterme, S.C., Mitchell, J.G., Seuront, L., 2008. The impact of turbulence and phytoplankton dynamics on foam formation, seawater viscosity and chlorophyll concentration in the eastern English Channel.

Kim, J.H., Park, B.S., Kim, J.-H., Wang, P., Han, M.-S., 2015. Intraspecific diversity and distribution of the cosmopolitan species Pseudo-nitzschia pungens (Bacillariophyceae): morphology, genetics, and ecophysiology of the three clades. J. Phycol. 51, 159-172. https://doi.org/10.1111/jpy.12263

Klein, C., Claquin, P., Bouchart, V., Le Roy, B., Véron, B., 2010. Dynamics of Pseudo-nitzschia spp. and domoic acid production in a macrotidal ecosystem of the Eastern English Channel (Normandy, France). Harmful Algae 9, 218-226. https://doi.org/10.1016/j.hal.2009.10.004

Kotaki, Y., Koike, K., Yoshida, M., Thuoc, C.V., Huyen, N.T.M., Hoi, N.C., Fukuyo, Y., Kodama, M., 2000. Domoic Acid Production in Nitzschia Sp. (bacillariophyceae) Isolated from a Shrimp-Culture Pond in Do Son, Vietnam. J. Phycol. 36, 1057-1060. https://doi.org/10.1046/j.15298817.2000.99209.x

Lamy, D., Artigas, L.F., Jauzein, C., Lizon, F., Cornille, V., 2006. Coastal bacterial viability and production in the eastern English Channel: A case study during a Phaeocystis globosa bloom. J. Sea Res. 56, 227-238. https://doi.org/10.1016/j.seares.2006.04.003

Le Borgne, P., Legendre, G., Marsouin, A., 2006. Validation of the OSI SAF radiative fluxes, in: Proceedings of the 2006 EUMETSAT Meteorological Satellite Conference, 12-16 June 2006. Presented at the EUMESAT Meteorological Satellite Conference, Helsinki, Finland. 
Leandro, L.F., Teegarden, G.J., Roth, P.B., Wang, Z., Doucette, G.J., 2010. The copepod Calanus finmarchicus: A potential vector for trophic transfer of the marine algal biotoxin, domoic acid. J. Exp. Mar. Biol. Ecol. 382, 88-95. https://doi.org/10.1016/j.jembe.2009.11.002

Lefebvre, A., Blondel, C., Cordier, R., Duquesne, V., Hébert, P., Vérin, F., 2014. Bulletin de surveillance de la qualité du milieu marin littoral 2013. Départements du Nord, Pas-de-Calais et de la Somme. Ifremer, Boulogne sur Mer, France.

Lefebvre, A., Guiselin, N., Barbet, F., Artigas, F.L., 2011. Long-term hydrological and phytoplankton monitoring (1992-2007) of three potentially eutrophic systems in the eastern English Channel and the Southern Bight of the North Sea. ICES J. Mar. Sci. J. Cons. 68, 2029-2043. https://doi.org/10.1093/icesjms/fsr149

Lefebvre, K.A., Silver, M.W., Coale, S.L., Tjeerdema, R.S., 2002. Domoic acid in planktivorous fish in relation to toxic Pseudo-nitzschia cell densities. Mar. Biol. 140, 625-631.

Legendre, P., Legendre, L.F.J., 1998. Numerical Ecology. Elsevier.

Lelong, A., Hégaret, H., Soudant, P., Bates, S.S., 2012. Pseudo-nitzschia (Bacillariophyceae) species, domoic acid and amnesic shellfish poisoning: revisiting previous paradigms. Phycologia 51, 168-216. https://doi.org/10.2216/11-37.1

Liefer, J.D., Robertson, A., MacIntyre, H.L., Smith, W.L., Dorsey, C.P., 2013. Characterization of a toxic Pseudo-nitzschia spp. bloom in the Northern Gulf of Mexico associated with domoic acid accumulation in fish. Harmful Algae 26, 20-32. https://doi.org/10.1016/j.hal.2013.03.002

Liu, H., Kelly, M.S., Campbell, D.A., Dong, S.L., Zhu, J.X., Wang, S.F., 2007. Exposure to domoic acid affects larval development of king scallop Pecten maximus (Linnaeus, 1758). Aquat. Toxicol. 81, 152-158. https://doi.org/10.1016/j.aquatox.2006.11.012

Lorenzen, C.J., 1966. A method for the continuous measurement of in vivo chlorophyll concentration. Deep Sea Res. Oceanogr. Abstr. 13, 223-227. https://doi.org/10.1016/0011-7471(66)91102-8

Louw, D.C., Doucette, G.J., Lundholm, N., 2018. Morphology and toxicity of Pseudo-nitzschia species in the northern Benguela Upwelling System. Harmful Algae 75, 118-128. https://doi.org/10.1016/j.hal.2018.04.008

Louw, D.C., Doucette, G.J., Voges, E., 2016. Annual patterns, distribution and long-term trends of Pseudo-nitzschia species in the northern Benguela upwelling system. J. Plankton Res. https://doi.org/10.1093/plankt/fbw079

Lundholm, N., 2018. Bacillariophyceae, in IOC-UNESCO Taxonomic Reference List of Harmful Micro Algae [WWW Document]. URL http://www.marinespecies.org/hab (accessed 8.9.18).

Lundholm, N., Clarke, A., Ellegaard, M., 2010. A 100-year record of changing Pseudo-nitzschia species in a sill-fjord in Denmark related to nitrogen loading and temperature. Harmful Algae 9, 449457. https://doi.org/10.1016/j.hal.2010.03.001

Lundholm, N., Hansen, P.J., Kotaki, Y., 2004. Effect of pH on growth and domoic acid production by potentially toxic diatoms of the genera Pseudo-nitzschia and Nitzschia. Mar. Ecol. Prog. Ser. 273, 1-15. https://doi.org/10.2307/24867469

Lundholm, N., Moestrup, Ø.J., 2000. Morphology of the Marine Diatom Nitzschia Navis-Varingica, Sp. Nov. (bacillariophyceae), Another Producer of the Neurotoxin Domoic Acid. J. Phycol. 36, 1162-1174. https://doi.org/10.1046/j.1529-8817.2000.99210.x

Maneiro, I., Iglesias, P., Guisande, C., Riveiro, I., Barreiro, A., Zervoudaki, S., Granéli, E., 2005. Fate of domoic acid ingested by the copepod Acartia clausi. Mar. Biol. 148, 123-130. https://doi.org/10.1007/s00227-005-0054-x

McKibben, S.M., Watkins-Brandt, K.S., Wood, A.M., Hunter, M., Forster, Z., Hopkins, A., Du, X., Eberhart, B.-T., Peterson, W.T., White, A.E., 2015. Monitoring Oregon Coastal Harmful Algae: Observations and implications of a harmful algal bloom-monitoring project. Harmful Algae 50, 32-44. https://doi.org/10.1016/j.hal.2015.10.004

Monchy, S., Grattepanche, J.-D., Breton, E., Meloni, D., Sanciu, G., Chabé, M., Delhaes, L., Viscogliosi, E., Sime-Ngando, T., Christaki, U., 2012. Microplanktonic Community Structure in a Coastal System Relative to a Phaeocystis Bloom Inferred from Morphological and Tag 
Pyrosequencing Methods. PLoS ONE 7, e39924.

https://doi.org/10.1371/journal.pone.0039924

Mullin, J.B., Riley, J.P., 1955. The colorimetric determination of silicate with special reference to sea and natural waters. Anal. Chim. Acta 12, 162-176. https://doi.org/10.1016/S00032670(00)87825-3

Murphy, J., Riley, J.P., 1962. A modified single solution method for the determination of phosphate in natural waters. Anal. Chim. Acta 27, 31-36. https://doi.org/10.1016/S0003-2670(00)88444-5

Orsini, L., Procaccini, G., Sarno, D., Montresor, M., 2004. Multiple rDNA ITS-types within the diatom Pseudo-nitzschia delicatissima (Bacillariophyceae) and their relative abundances across a spring bloom in the Gulf of Naples. Mar. Ecol. Prog. Ser. 271, 87-98. https://doi.org/10.3354/meps271087

Parsons, M.L., Dortch, Q., Turner, R.E., 2002. Sedimentological evidence of an increase in Pseudonitzschia (Bacillariophyceae) abundance in response to coastal eutrophication. Limnol. Oceanogr. 47, 551-558.

Parsons, M.L., Okolodkov, Y.B., Aké-Castillo, J.A., 2012. Diversity and morphology of the species of Pseudonitzschia (Bacillariophyta) of the National Park Sistema Arrecifal Veracruzano, SW Gulf of Mexico. Acta Bot. Mex.

Peperzak, L., Gäbler-Schwarz, S., 2012. Current Knowledge of the Life Cycles of Phaeocystis Globosa and Phaeocystis Antarctica (prymnesiophyceae)1. J. Phycol. 48, 514-517. https://doi.org/10.1111/j.1529-8817.2012.01136.x

Prince, E.K., Irmer, F., Pohnert, G., 2013. Domoic Acid Improves the Competitive Ability of Pseudonitzschia delicatissima against the Diatom Skeletonema marinoi. Mar. Drugs 11, 2398-2412. https://doi.org/10.3390/md11072398

Pugliese, L., Casabianca, S., Perini, F., Andreoni, F., Penna, A., 2017. A high resolution melting method for the molecular identification of the potentially toxic diatom Pseudo-nitzschia spp. in the Mediterranean Sea. Sci. Rep. 7, 4259. https://doi.org/10.1038/s41598-017-04245-z

Quijano-Scheggia, S.I., Garcés, E., Lundholm, N., Moestrup, Ø., Andree, K., Camp, J., 2009. Morphology, physiology, molecular phylogeny and sexual compatibility of the cryptic Pseudo-nitzschia delicatissima complex (Bacillariophyta), including the description of $\mathrm{P}$. arenysensis sp. nov. Phycologia 48, 492-509. https://doi.org/10.2216/08-21.1

R Core Team, 2012. R: A language and environmet for statistical computing. R Foundation for Statistical Computing, Vienna, Austria.

REPHY, Laboratoire Environnement Ressources Boulogne sur Mer, 2017. Qualité du Milieu Marin Littoral - Bulletin de la surveillance 2016. Ifremer.

Rhodes, L., Scholin, C., Garthwaite, I., 1998. Pseudo-nitzschia in New Zealand and the role of DNA probes and immunoassays in refining marine biotoxin monitoring programmes. Nat. Toxins 6 , 105-111. https://doi.org/10.1002/(SICI)1522-7189(199805/08)6:3/4<105::AIDNT13>3.0.CO;2-9

Rousseau, V., Chrétiennot-Dinet, M.-J., Jacobsen, A., Verity, P., Whipple, S., 2007. The life cycle of Phaeocystis: state of knowledge and presumptive role in ecology. Biogeochemistry 83, 2947. https://doi.org/10.1007/s10533-007-9085-3

Rue, E., Bruland, K., 2001. Domoic acid binds iron and copper: a possible role for the toxin produced by the marine diatom Pseudo-nitzschia. Mar. Chem. 76, 127-134. https://doi.org/10.1016/S0304-4203(01)00053-6

Sahraoui, I., Bates, S.S., Bouchouicha, D., Mabrouk, H.H., Hlaili, A.S., 2011. Toxicity of Pseudonitzschia populations from Bizerte Lagoon, Tunisia, southwest Mediterranean, and first report of domoic acid production by P. brasiliana. Diatom Res. 26, 293-303. https://doi.org/10.1080/0269249X.2011.597990

Sazhin, A.F., Artigas, L.F., Nejstgaard, J.C., Frischer, M.E., 2007. The colonization of two Phaeocystis species (Prymnesiophyceae) by pennate diatoms and other protists: a significant contribution to colony biomass. Biogeochemistry 83, 137-145. https://doi.org/10.1007/s10533-007-90862 
Schapira, M., Vincent, D., Gentilhomme, V., Seuront, L., 2008. Temporal patterns of phytoplankton assemblages, size spectra and diversity during the wane of a Phaeocystis globosa spring bloom in hydrologically contrasted coastal waters. J. Mar. Biol. Assoc. U. K. 88, 649-662. https://doi.org/10.1017/S0025315408001306

Schoemann, V., Becquevort, S., Stefels, J., Rousseau, V., Lancelot, C., 2005. Phaeocystis blooms in the global ocean and their controlling mechanisms: a review. J. Sea Res., Iron Resources and Oceanic Nutrients - Advancement of Global Environmental Simulations 53, 43-66. https://doi.org/10.1016/j.seares.2004.01.008

Scholin, C.A., Gulland, F., Doucette, G.J., Benson, S., Busman, M., Chavez, F.P., Cordaro, J., DeLong, R., De Vogelaere, A., Harvey, J., Haulena, M., Lefebvre, K., Lipscomb, T., Loscutoff, S., Lowenstine, L.J., Marin Iii, R., Miller, P.E., McLellan, W.A., Moeller, P.D.R., Powell, C.L., Rowles, T., Silvagni, P., Silver, M., Spraker, T., Trainer, V., Van Dolah, F.M., 2000. Mortality of sea lions along the central California coast linked to a toxic diatom bloom. Nature 403, 8084. https://doi.org/10.1038/47481

Seuront, L., Vincent, D., Mitchell, J.G., 2006. Biologically induced modification of seawater viscosity in the Eastern English Channel during a Phaeocystis globosa spring bloom. J. Mar. Syst. 61, 118133. https://doi.org/10.1016/j.jmarsys.2005.04.010

Sierra-Beltran, A.P., Palafox-Uribe, M., Grajales-Montiel, J., Cruz-Villacorta, A., Ochoa, J.L., 1997. Sea bird mortality at Cabo San Lucas, Mexico: evidence that toxic diatom blooms are spreading. Toxicon 35, 447-453.

Sobrinho, B.F., de Camargo, L.M., Sandrini-Neto, L., Kleemann, C.R., Machado, E. da C., Mafra, L.L., 2017. Growth, Toxin Production and Allelopathic Effects of Pseudo-nitzschia multiseries under Iron-Enriched Conditions. Mar. Drugs 15, 331. https://doi.org/10.3390/md15100331

Sommer, U., 1994. Are marine diatoms favoured by high Si:N ratios? Mar. Ecol. Prog. Ser. 115, 309315. https://doi.org/10.2307/24849755

Stauffer, B., Gellene, A., Schnetzer, A., Seubert, E., Oberg, C., Sukhatme, G., Caron, D., 2012. An oceanographic, meteorological, and biological 'perfect storm' yields a massive fish kill. Mar. Ecol. Prog. Ser. 468, 231-243. https://doi.org/10.3354/meps09927

Tammilehto, A., Nielsen, T.G., Krock, B., Møller, E.F., Lundholm, N., 2015. Induction of domoic acid production in the toxic diatom Pseudo-nitzschia seriata by calanoid copepods. Aquat. Toxicol. Amst. Neth. 159, 52-61. https://doi.org/10.1016/j.aquatox.2014.11.026

Tan, S.N., Teng, S.T., Lim, H.C., Kotaki, Y., Bates, S.S., Leaw, C.P., Lim, P.T., 2016. Diatom Nitzschia navis-varingica (Bacillariophyceae) and its domoic acid production from the mangrove environments of Malaysia. Harmful Algae 60, 139-149. https://doi.org/10.1016/j.hal.2016.11.003

Tas, S., Dursun, F., Aksu, A., Balkis, N., 2016. Presence of the diatom genus Pseudo-nitzschia and particulate domoic acid in the Golden Horn Estuary (Sea of Marmara, Turkey). Diatom Res. 31, 339-349. https://doi.org/10.1080/0269249X.2016.1247020

Tas, S., Lundholm, N., 2016. Temporal and spatial variability of the potentially toxic <span class="italic">Pseudo-nitzschia</span>spp. in a eutrophic estuary (Sea of Marmara). J. Mar. Biol. Assoc. U. K. 1-12. https://doi.org/10.1017/S0025315416000837

Terenko, L., Terenko, G., 2012. Dominant Pseudo-Nitzschia (Bacillariophyta) species in the Black Sea (Ukraine). Bot. Lith. 18, 27-34. https://doi.org/10.2478/v10279-012-0004-8

Thessen, A.E., Bowers, H.A., Stoecker, D.K., 2009. Intra- and interspecies differences in growth and toxicity of Pseudo-nitzschia while using different nitrogen sources. Harmful Algae, This issue contains the special section on "Strains" 8, 792-810. https://doi.org/10.1016/j.hal.2009.01.003

Thessen, A.E., Dortch, Q., Parsons, M.L., Morrison, W., 2005. Effect of Salinity on Pseudo-Nitzschia Species (bacillariophyceae) Growth and Distribution1. J. Phycol. 41, 21-29. https://doi.org/10.1111/j.1529-8817.2005.04077.x

Thorel, M., Claquin, P., Schapira, M., Le Gendre, R., Riou, P., Goux, D., Le Roy, B., Raimbault, V., Deton-Cabanillas, A.-F., Bazin, P., Kientz-Bouchart, V., Fauchot, J., 2017. Nutrient ratios 
influence variability in Pseudo-nitzschia species diversity and particulate domoic acid production in the Bay of Seine (France). Harmful Algae 68, 192-205. https://doi.org/10.1016/j.hal.2017.07.005

Trainer, V.L., Bates, S.S., Lundholm, N., Thessen, A.E., Cochlan, W.P., Adams, N.G., Trick, C.G., 2012. Pseudo-nitzschia physiological ecology, phylogeny, toxicity, monitoring and impacts on ecosystem health. Harmful Algae 14, 271-300. https://doi.org/10.1016/j.hal.2011.10.025

Trainer, V.L., Hickey, B.M., Bates, S.S., 2008. Toxic diatoms. Oceans Hum. Health Risks Remedies Sea 219-237.

Trick, C.G., Bill, B.D., Cochlan, W.P., Wells, M.L., Trainer, V.L., Pickell, L.D., 2010. Iron enrichment stimulates toxic diatom production in high-nitrate, low-chlorophyll areas. Proc. Natl. Acad. Sci. 107, 5887-5892. https://doi.org/10.1073/pnas.0910579107

Verity, P.G., Whipple, S.J., Nejstgaard, J.C., Alderkamp, A.-C., 2007. Colony size, cell number, carbon and nitrogen contents of Phaeocystis pouchetii from western Norway. J. Plankton Res. 29, 359-367. https://doi.org/10.1093/plankt/fbm021

Villac, M.C., Roelke, D.L., Villareal, T.A., Fryxell, G.A., 1993. Comparison of two domoic acid-producing diatoms: a review, in: Twelfth International Diatom Symposium, Developments in Hydrobiology. Springer, Dordrecht, pp. 213-224. https://doi.org/10.1007/978-94-017-36220_23

Walz, P.M., Garrison, D.L., Graham, W.M., Cattey, M.A., Tjeerdema, R.S., Silver, M.W., 1994. Domoic acid-producing diatom blooms in Monterey Bay, California: 1991-1993. Nat. Toxins 2, 271279. https://doi.org/10.1002/nt.2620020505

Widdicombe, C.E., Eloire, D., Harbour, D., Harris, R.P., Somerfield, P.J., 2010. Long-term phytoplankton community dynamics in the Western English Channel. J. Plankton Res. 32, 643-655. https://doi.org/10.1093/plankt/fbp127

Zabaglo, K., Chrapusta, E., Bober, B., Kaminski, A., Adamski, M., Bialczyk, J., 2016. Environmental roles and biological activity of domoic acid: A review. Algal Res. 13, 94-101. https://doi.org/10.1016/j.algal.2015.11.020 


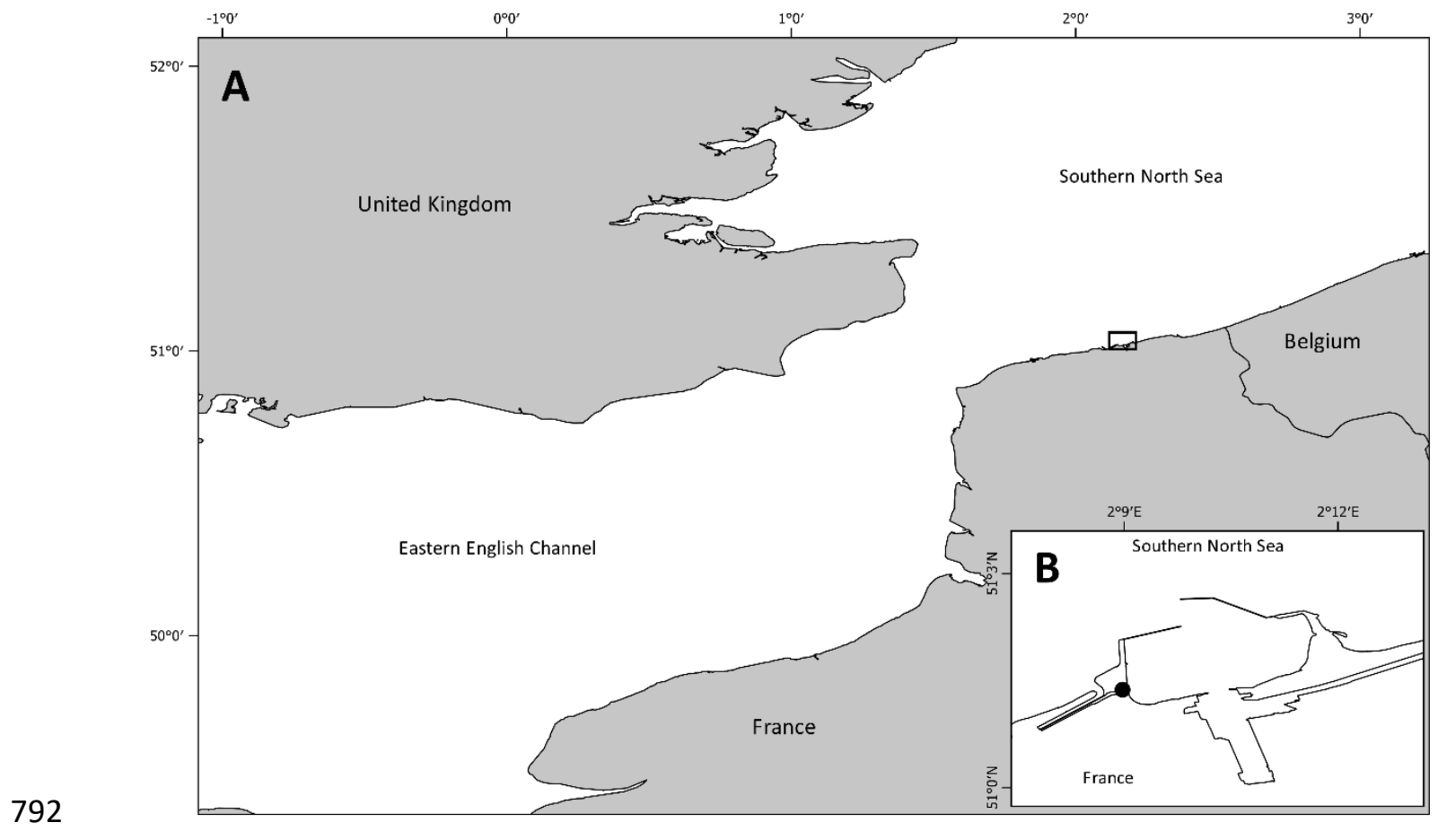

793 Figure 1. A - Location of the study area. B - Location of the sampling station (black dot) in 794 Dunkirk harbor (Southern Bight of the North Sea). 

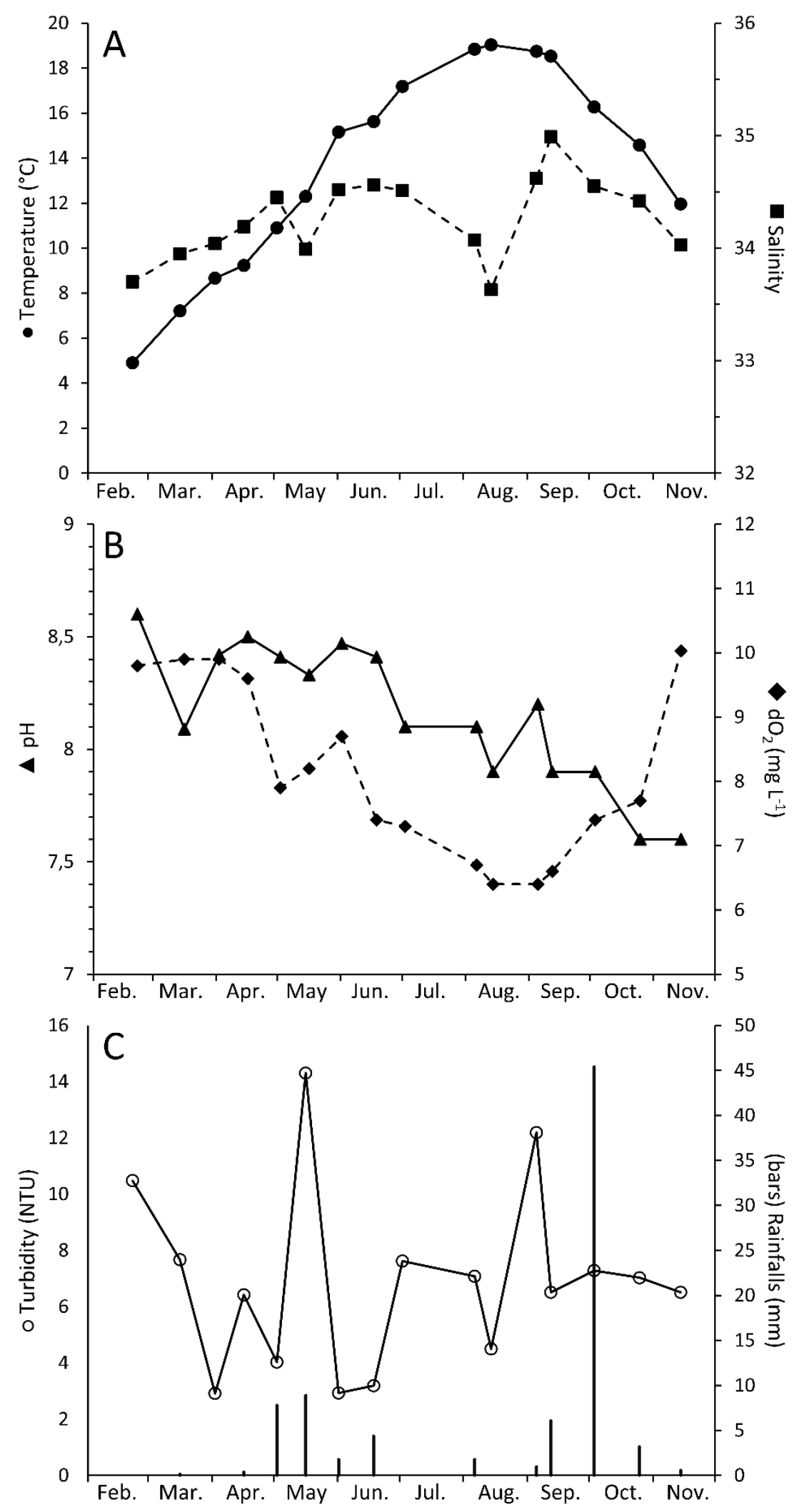

Figure 2. Time series of meteorological and hydrological parameters. A. Temperature $\left({ }^{\circ} \mathrm{C}\right)$ and salinity, B. pH and dO2 (mg L-1), C. Turbidity (NTU) and cumulated rainfalls over three days (bars, mm) during the 2012 survey. 

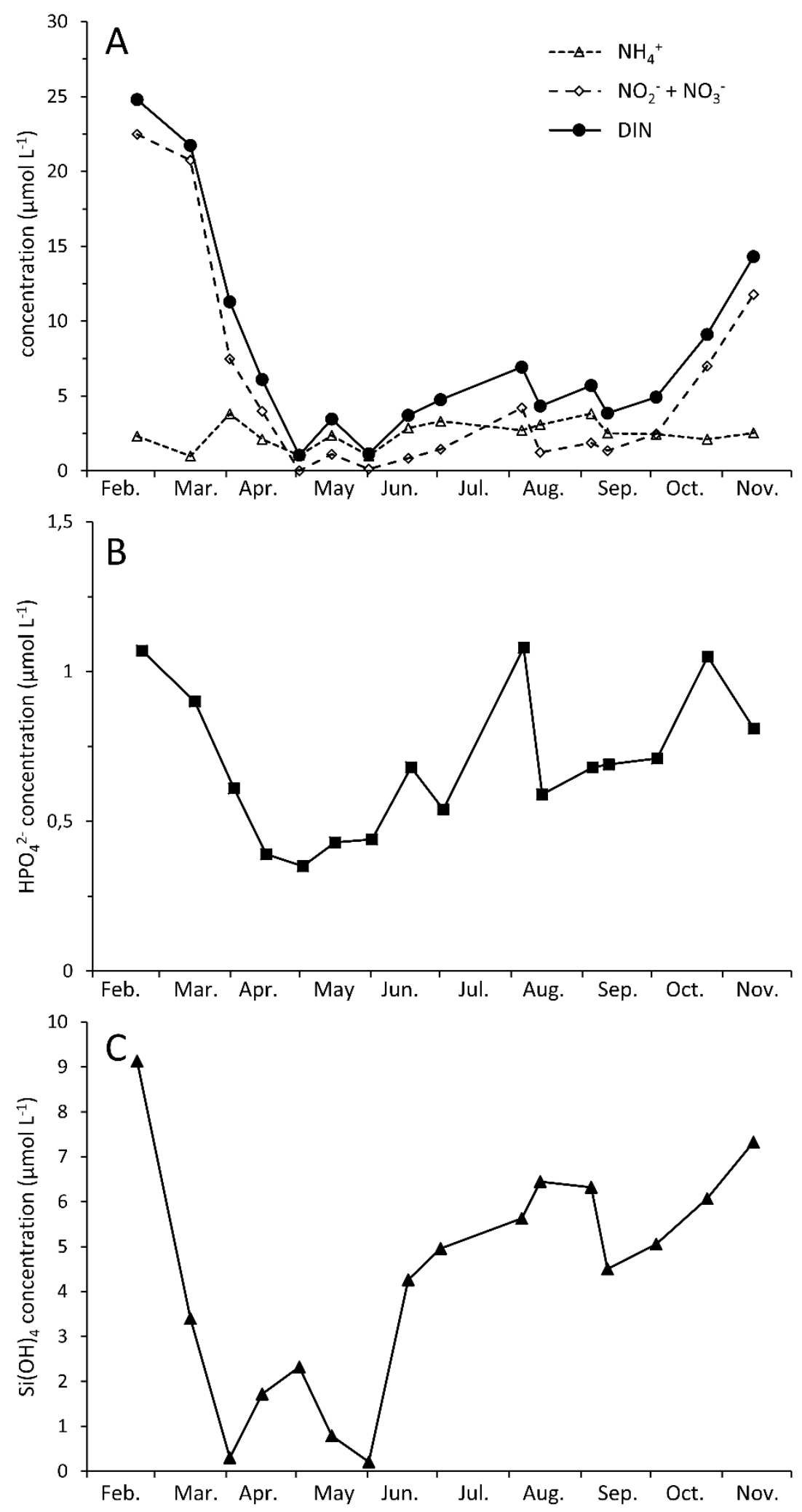

Figure 3. time series of nutrient concentrations ( $\left.\mu \mathrm{mol} \mathrm{L} \mathrm{L}^{-1}\right)$. A. $\mathrm{NO}_{2}+\mathrm{NO}_{3}, \mathrm{NH}_{4}{ }^{+}$and total 803 dissolved inorganic nitrogen ( $\left.\mathrm{DIN}=\mathrm{NO}_{2}+\mathrm{NO}_{3^{-}}+\mathrm{NH}_{4^{+}}\right)$. B. $\mathrm{HPO}_{4^{2}}$. C. Si(OH) $)_{4}$ during the 8042012 survey. 

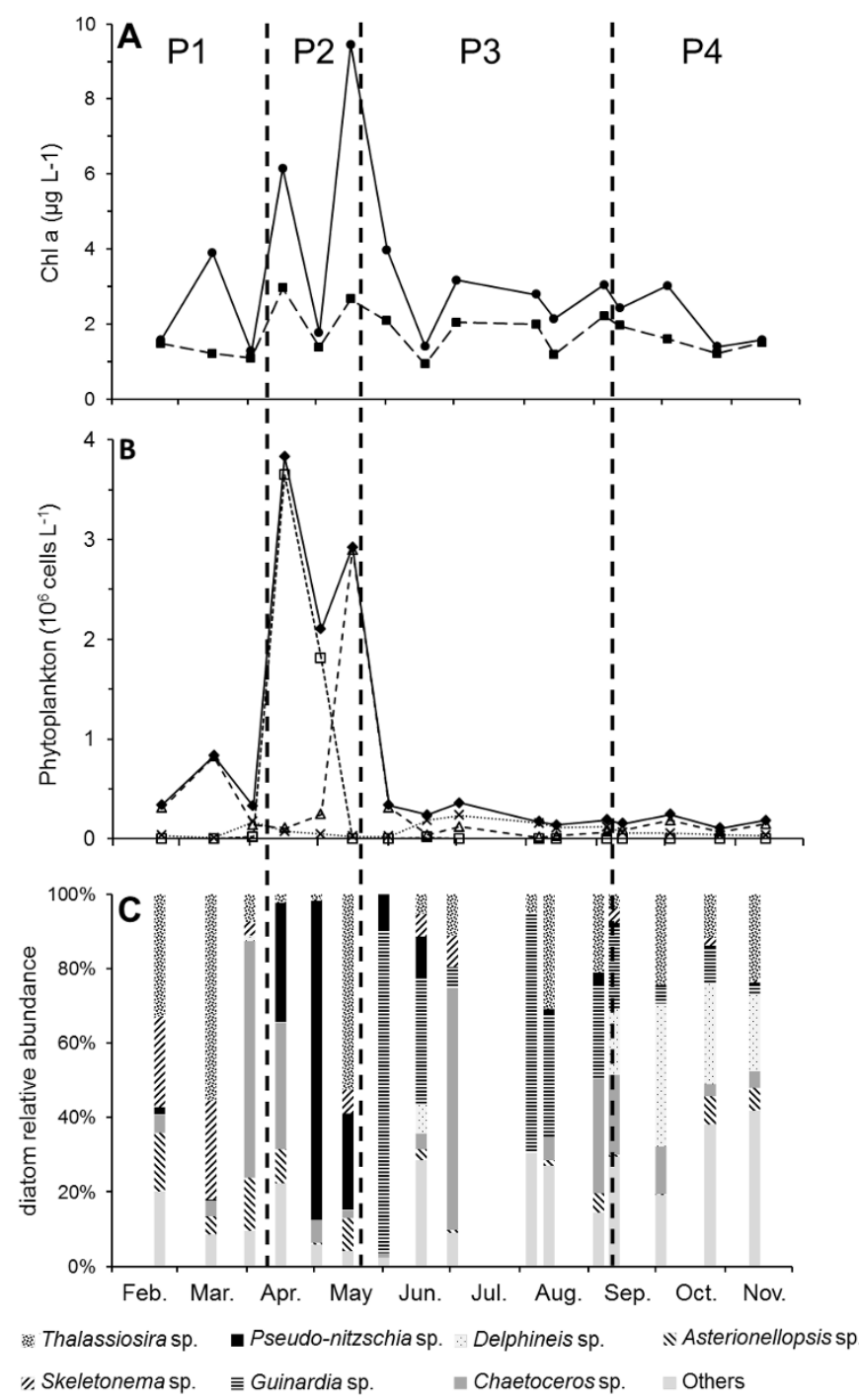

806

807 Figure 4. Time series of A. Chlorophyll $a(\bullet)$ and pheopigment $(\boldsymbol{\square})$ concentrations $\left(\mu \mathrm{L}^{-1}\right)$;

808 B. Abundance (cell L-1) of total phytoplankton ( $\bullet$ ), diatoms $(\Delta)$ ), Phaeocystis globosa $(\square)$ and 809 other phytoplankton groups $(\times)$; and C. relative abundance of diatom genus (\%) during the 8102012 survey. 



814 Figure 5. SEM micrographs of the three identified Pseudo-nitzschia species. A-B: Pseudo815 nitzschia delicatissima; C-d: Pseudo-nitzschia pungens; E-F: Pseudo-nitzschia fraudulenta. 816 Scale bars: A, C, $\mathrm{E}=1 \mu \mathrm{m}, \mathrm{B}, \mathrm{D}, \mathrm{F}=10 \mu \mathrm{m}$. 


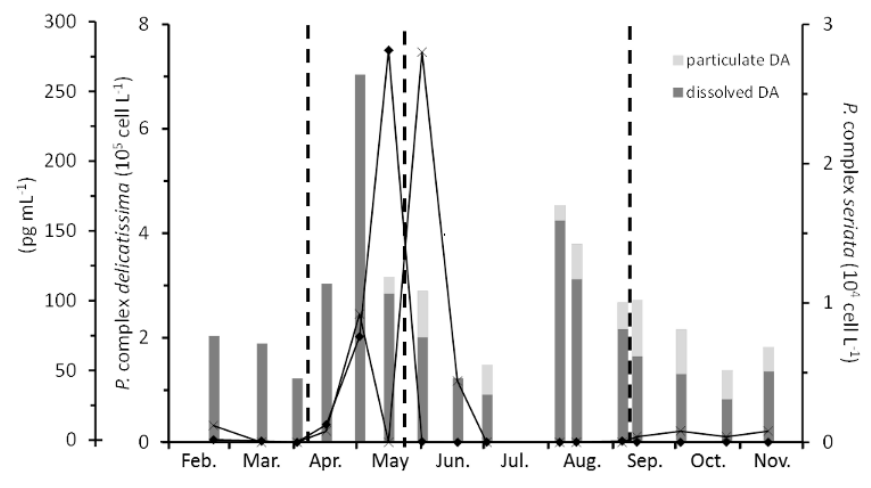

818 Figure 6: Time series of Pseudo-nitzschia complex delicatissima $(\diamond)$ and $P$. complex seriata $819(\times)$ abundances (cell $\mathrm{L}^{-1}$ ), and particulate and dissolved domoic acid (DA, pg $\mathrm{mL}^{-1}$ ) during the 8202012 survey. Stars below the x axis indicate the dates of SEM analyses for Pseudo-nitzschia 821 sp. diversity. 

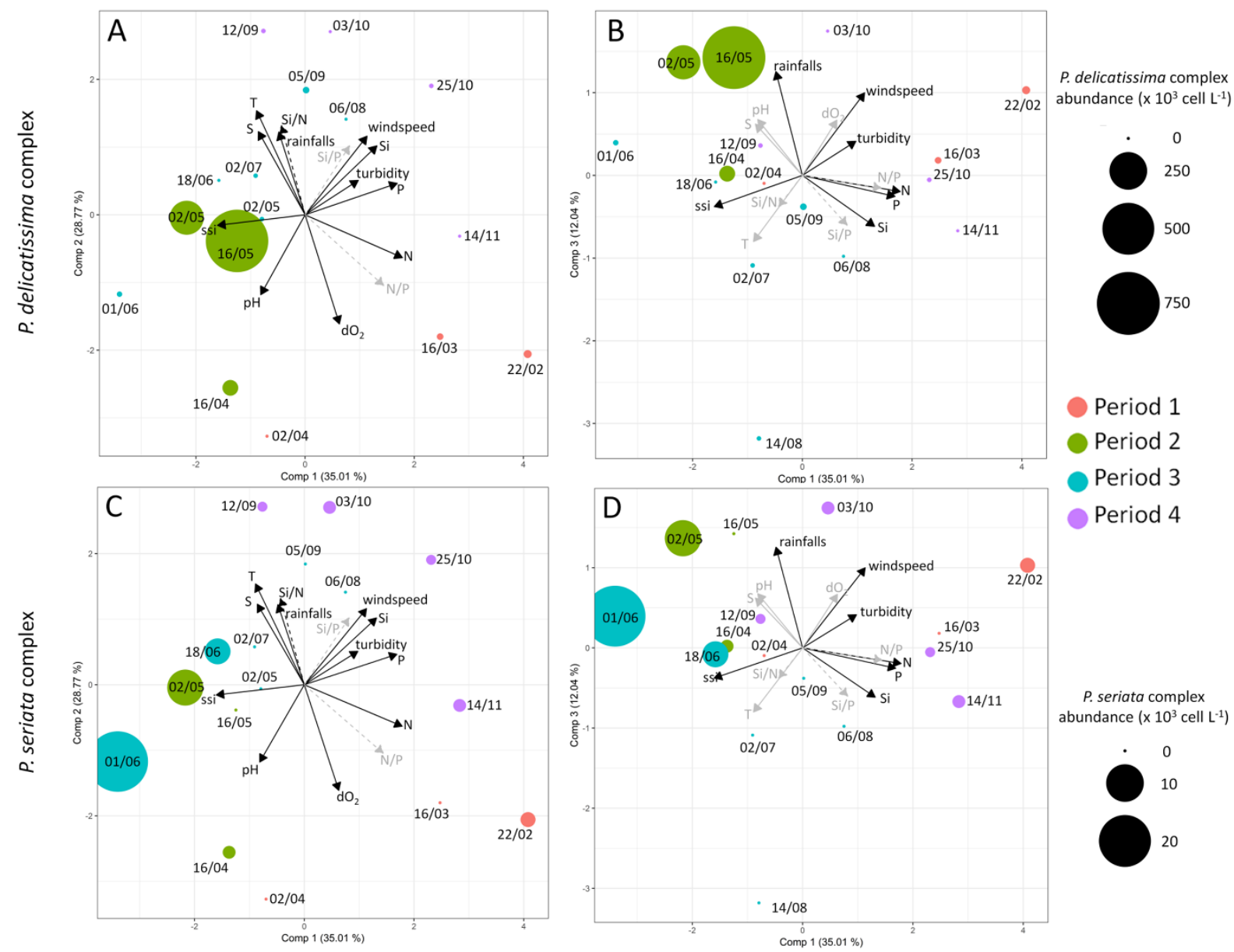

824 Figure 7: PCA plots of environmental variables. A and C. Plane defined by the two first axes 825 of the PCA (PC1 and PC2) B and D. plane defined by the first (PC1) and third axis (PC3) of 826 the PCA (B and D). Points correspond to sampling dates. The colors of the circles correspond 827 to the periods (P1 to P4) determined from phytoplankton communities composition. Circles 828 size is proportional to Pseudo-nitzschia abundance (cell $\mathrm{L}^{-1}$ ) for $P$. complex delicatissima (A and $\mathrm{B}$ ) and $P$. complex seriata (C and $\mathrm{D})$. Black arrows represent variables significantly correlated to at least one represented PC. 
Table 1. Morphological features of Pseudo-nitzschia species and comparison with literature values (min-max). * correspond to one frustule analysed and presenting outliers in poroids features (among >300 identified frustules)

\begin{tabular}{|c|c|c|c|c|c|c|c|c|}
\hline Species & $\begin{array}{l}\text { Width } \\
\mu \mathrm{m}\end{array}$ & $\begin{array}{l}\text { Length } \\
\mu \mathrm{m}\end{array}$ & $\begin{array}{l}\text { Central } \\
\text { Interspace }\end{array}$ & $\begin{array}{l}\text { Fibulae } \\
10 \mu \mathrm{m}^{-1}\end{array}$ & $\begin{array}{l}\text { Interstriae } \\
10 \mu \mathrm{m}^{-1}\end{array}$ & $\begin{array}{l}\text { Rows of } \\
\text { poroids }\end{array}$ & $\begin{array}{l}\text { Poroids } \\
1 \mu \mathrm{m}^{-1}\end{array}$ & Reference \\
\hline \multirow{11}{*}{ P. delicatissima } & $1.3-2$ & N/A & + & $22-29$ & $33-43$ & 2 & $8-11$ & Amato et al., 2005 \\
\hline & $1.7-2.8$ & N/A & + & $20-27$ & $24-40$ & 2 & $8-14$ & Fehling et al., 2006 \\
\hline & $1.1-2$ & $40-78$ & + & $19-25$ & $36-40$ & 2 & $10-12$ & Skov et al., 1999 \\
\hline & $1.0-1.5$ & $42-66$ & + & $20-23$ & env 40 & 2 & $10-12$ & Hasle et al., 1996 \\
\hline & $1.7-2.3$ & $17-48$ & + & $18-36$ & $37-44$ & 2 & 7.5-13.4 & Kaczmarska et al., 2008 \\
\hline & $1.3-1.6$ & $48-49$ & - & $22-23$ & $36-40$ & 2 & $8-9$ & Klein et al., 2010 \\
\hline & $1.5-2.0$ & $19-76$ & N/A & $19-26$ & $35-40$ & 2 & 12 & Lundholm et al., 2006 \\
\hline & $1.3-1.6$ & $34-46$ & + & $24-28$ & $41-45$ & 2 & 7-11 & Moschandreou and Nikolaidis, 2010 \\
\hline & $1.0-2.4$ & $19-78$ & + & $19-30$ & $33-42$ & 2 & $8-12.5$ & Quijano-Scheggia et al., 2010 \\
\hline & $1.4-2.6$ & $31-48$ & + & $20-28$ & $38-41$ & 2 & 8-12 & Fernandes et al 2014 \\
\hline & 1.1-1.7 & 40.7-67.1 & + & $18-27$ & $34-44$ & $2(3 *)$ & $10-14(18 *)$ & This study \\
\hline \multirow[t]{10}{*}{ P. fraudulenta } & $4.3-5.1$ & N/A & + & $20-24$ & $22-26$ & $2-3$ & $5-6$ & Fehling et al., 2006 \\
\hline & 4.5-10 & $50-119$ & + & $12-24$ & $18-24$ & $2-3$ & $5-7$ & Skov et al., 1999 \\
\hline & $5-6$ & $73-117$ & + & $19-23$ & $19-23$ & $2-3$ & $4-5$ & Hasle et al., 1996 \\
\hline & $3-4.5$ & 63-99 & + & $15-17$ & $14-15$ & 2 & N/A & Hernández-Becerril, 1998 \\
\hline & $5.1-5.6$ & $56.8-81$ & - & $21-22$ & $22-24$ & $2-3$ & 6-7 & Klein et al., 2010 \\
\hline & $4-7$ & 71-101 & N/A & $18-30$ & $19-28$ & $2-3$ & $6-7$ & Ljubešić et al., 2011 \\
\hline & 4.4-5.8 & $48-80$ & + & $22-24$ & $21-24$ & 2 & $5-6$ & Moschandreou and Nikolaidis, 2010 \\
\hline & 2.9-7.1 & 38.9-131.5 & + & $12-24$ & $18-24$ & 2 & $4-7$ & Quijano-Scheggia et al., 2010 \\
\hline & $5.2-6.2$ & $64-84$ & + & $20-23$ & $22-23$ & 2 & $5-6$ & Fernandes et al. 2014 \\
\hline & $5.2-6.1$ & 75.0-98.8 & + & $19-23$ & $17-23$ & $2-3$ & $6-7$ & This study \\
\hline \multirow[t]{11}{*}{ P. pungens } & 3.1 & $\mathrm{~N} / \mathrm{A}$ & - & 12 & 12 & 2 & $3-4$ & Fehling et al., 2006 \\
\hline & $2.4-5.3$ & $74-174$ & - & $9-16$ & $9-16$ & $1-2$ & $3-4$ & Skov et al., 1999 \\
\hline & $2.9-4.5$ & $74-142$ & - & $9-15$ & $9-15$ & 2 & $3-4$ & Hasle et al., 1996 \\
\hline & $3-4$ & $94-109$ & - & $10-11$ & $10-12$ & 2 & N/A & Hernández-Becerril, 1998 \\
\hline & $2.9-3.3$ & $61-106$ & - & $11-13$ & $11-14$ & $2-3$ & $2-4$ & Klein et al., 2010 \\
\hline & 3.9-5.7 & $88-105$ & & $10-17$ & 8-15 & 2 & $2-4$ & Ljubešić et al., 2011 \\
\hline & 2.5-3.6 & 77-101 & - & $11-13$ & $11-13$ & 2 & $2-4$ & Moschandreou and Nikolaidis, 2010 \\
\hline & $2-4.8$ & $37-156$ & - & $9-13$ & $9-15$ & 2 & $1-5$ & Quijano-Scheggia et al., 2010 \\
\hline & $4-4.5$ & $75-130$ & - & $9-13$ & N/A & 2 & $3-4$ & Stonik et al., 2001 \\
\hline & $3.0-4.1$ & $72-149$ & - & $11-13$ & $10-12$ & 2 & $3-4$ & Fernandes et al 2014 \\
\hline & 2.7-4.7 & 95.9-135.5 & - & 10-15 & 10-15 & $2-3$ & $2-4$ & This study \\
\hline
\end{tabular}


Table 2. Spearman correlation coefficient between principal components (PCx), environmental parameters, Pseudo-nitzschia complexes abundances and domoic acid concentration.

\begin{tabular}{lccc} 
Parameters & PC1 & PC2 & PC3 \\
\hline Main variables & & & \\
Temperature (T) & -0.18 & $0.73^{* *}$ & -0.45 \\
Salinity (S) & -0.39 & $0.64^{* *}$ & 0.13 \\
pH & $0.43^{+}$ & $-0.64^{* *}$ & 0.29 \\
dO $_{2}$ & 0.22 & $-0.75^{* * *}$ & 0.26 \\
Turbidity & $0.498^{*}$ & 0.22 & 0.15 \\
Rainfalls & -0.29 & $0.55^{*}$ & $0.61^{*}$ \\
Windspeed & $0.61^{*}$ & $0.51^{*}$ & 0.47 \\
Surface Solar Irradiance (ssi) & $-0.74^{* *}$ & -0.06 & -0.15 \\
DIN $_{\text {PO }}{ }^{2 *}$ & $0.88^{* * *}$ & -0.29 & -0.25 \\
Si(OH) $_{4}$ & $0.87^{* * *}$ & 0.28 & -0.15 \\
& $0.69^{* * *}$ & 0.37 & -0.38
\end{tabular}

Supplementary variables

$\begin{array}{lccc}\mathrm{Si} / \mathrm{P} & 0.26 & 0.44 & -0.38 \\ \mathrm{Si} / \mathrm{N} & -0.23 & 0.69 * * & -0.19 \\ \mathrm{~N} / \mathrm{P} & 0.66 * * & -0.50 * & -0.20\end{array}$

Pseudo-nitzschia and DA

$\begin{array}{lccc}\text { P. delicatissima complex } & -0.27 & -0.33 & 0.47^{+} \\ \text {P. seriata complex } & -0.31 & -0.07 & 0.50^{*} \\ \text { tDA } & -0.30 & 0.12 & 0.20 \\ \text { (* p-value }<0.05, * * \text { p-value }<0.01, * * * & \text { p-value }<0.001)\end{array}$


Table 3. Environmental features of Pseudo-nitzschia spp. identified during the 2012 survey and literature values.

\begin{tabular}{|c|c|c|c|c|c|c|c|c|c|}
\hline Species & Location & $\begin{array}{l}\text { Temperature } \\
{ }^{\circ} \mathrm{C} \\
\end{array}$ & Salinity & $\begin{array}{l}\text { DIN } \\
\mu \mathrm{mol} \mathrm{L} \mathrm{L}^{-1}\end{array}$ & $\begin{array}{l}\text { PO4 } \\
\mu \mathrm{mol} \mathrm{L} \mathrm{L}^{-1}\end{array}$ & $\begin{array}{l}\text { Si } \\
\mu \mathrm{mol} \mathrm{L} \mathrm{L}^{-1}\end{array}$ & $\begin{array}{l}\text { Abundance } \\
\text { cells } \mathrm{L}^{-1}\end{array}$ & DA & Reference \\
\hline \multirow[t]{7}{*}{ P. delicatissima } & Southern Adriatic Sea & $\begin{array}{l}\text { 8.79-29.91, } \\
\mathrm{R}<0\end{array}$ & $\mathrm{R}>0$ & \multicolumn{3}{|c|}{ no significant pattern } & nd & nd & Caroppo et al., 2005 \\
\hline & Western Scottland & $\sim 8^{\circ} \mathrm{C}$ & nd & $\sim 3 \mu \mathrm{M}$ & $\sim 0.3 \mu \mathrm{M}$ & $\sim 2.5 \mu \mathrm{M}$ & $1.6 \cdot 10^{5}$ & nd & Fehling et al., 2006 \\
\hline & Louisiana & nd & & \multicolumn{2}{|c|}{ no significant pattern } & & $1 \cdot 10^{6}$ & 5.5pg cell ${ }^{-1}$ & Parsons et al., 2013 \\
\hline & NE Spanish Coast & $\mathrm{R}>0$ & $\begin{array}{l}36.8 \pm 1.1 \\
\mathrm{R}<0\end{array}$ & $\mathrm{R}>0$ & $\begin{array}{l}\text { nd } \\
\text { no significar }\end{array}$ & $\begin{array}{l}\text { nd } \\
\text { nt }\end{array}$ & $17.6 \pm 5.2 \cdot 10^{5}$ & nd & $\begin{array}{l}\text { Quijano-Scheggia et al., } \\
2008\end{array}$ \\
\hline & Bay of Fundy & nd & nd & $\mathrm{R}>0$ & correlation & & nd & & Kaczmarska et al., 2007 \\
\hline & Gulf of maine & nd & nd & nd & nd & nd & nd & $\begin{array}{l}111-390 \mathrm{Pg} \\
\mathrm{mL}^{-1}\end{array}$ & Fernandes et al., 2014 \\
\hline & Black Sea & $16-17.5$ & $14.5-15.7$ & nd & nd & nd & $1.5-3.1 \cdot 10^{6}$ & nd & \\
\hline \multirow[t]{3}{*}{ P. delicatissima complex } & Western English Channel & déc-15 & $\begin{array}{l}34.9 \pm 0.4 \\
R>0\end{array}$ & nd & $\mathrm{R}<0$ & nd & $2,5 \cdot 10^{5}$ & $\begin{array}{l}0.2-0.4 \mathrm{pg} \\
\mathrm{mL}^{-1}\end{array}$ & $\begin{array}{l}\text { Downes-Tettmar et al., } \\
2013\end{array}$ \\
\hline & Galicia - Spain & $\sim 13.1$ & $\sim 35.6$ & $\sim 2.1$ & $\sim 0.22$ & $\sim 3$ & $6.6 \cdot 10^{5}$ & not detected & Díaz et al., 2014 \\
\hline & $\begin{array}{l}\text { Southern Bight of the } \\
\text { North Sea }\end{array}$ & $9-12$ & $34.2 \pm 0.2$ & $\begin{array}{l}3.5 \pm 2.5 \\
\text { decreasing }\end{array}$ & $0.39 \pm 0.04$ & $1.6 \pm 0.8$ & $33 \cdot 10^{3}-7.5 \cdot 10^{5}$ & $\begin{array}{l}\text { 92-229pg } \\
\mathrm{mL}^{-1}\end{array}$ & This study \\
\hline \multirow[t]{7}{*}{ P. pungens } & Louisiana & nd & nd & $\mathrm{R}<0$ & $\mathrm{R}>0$ & no corr & 50000 & nd & \multirow{2}{*}{$\begin{array}{l}\text { Parsons et al., } 2013 \\
\text { Quijano-Scheggia et al., } \\
2008\end{array}$} \\
\hline & NE Spanish Coast & nd & nd & no pattern & nd & nd & nd & $\begin{array}{l}\text { nd } \\
40-1100 \mathrm{pg}\end{array}$ & \\
\hline & Gulf of Maine & nd & nd & $\mathrm{Nd}$ & nd & nd & nd & $\mathrm{mL}^{-1}$ & \multirow{7}{*}{$\begin{array}{l}\text { Fernandes et al., } 2014 \\
\text { Kaczmarska et al., } 2007 \\
\text { Downes-Tettmar et al., } \\
2013 \\
\text { Tas and Lundholm, } \\
2016 \\
\text { Tas et al., } 2016 \\
\text { Gárate-Lizárraga et al., } \\
2007 \\
\text { Quijano-Scheggia et al., } \\
2008\end{array}$} \\
\hline & Bay of Fundy & nd & nd & $\mathrm{R}<0$ & $\mathrm{R}>0$ & nd & nd & $\begin{array}{l}\text { nd } \\
0.2-0.4 \mathrm{pg}\end{array}$ & \\
\hline & Western English Channel & $12-16$ & $34.9 \pm 0.4$ & $\mathrm{R}<0$ & $\mathrm{R}<0$ & $\mathrm{R}<0$ & 25000 & & \\
\hline & Sea of Marmara,Turkey & $11.6-22.8$ & 21.6 & nd & nd & 1.8 & $4.8 \cdot 10^{5}$ & nd & \\
\hline & Sea of Marmara,Turkey & $7.4-26.3$ & 15.9-19.9 & $\mathrm{Nd}$ & $\mathrm{Nd}$ & $\mathrm{Nd}$ & $1.6-1.7 \cdot 10^{4}$ & 1.0pg mL $\mathrm{mL}^{-1}$ & \\
\hline \multirow[t]{2}{*}{ P. fraudulenta } & \multirow{2}{*}{$\begin{array}{l}\text { California } \\
\text { North Western } \\
\text { Mediterannean Sea }\end{array}$} & 18.5-26.5 & nd & $0-3$ & nd & $2.9-35.5$ & $5-1310^{5}$ & detected & \\
\hline & & nd & $\mathrm{R}>0$ & $\mathrm{R}<0$ & nd & nd & nd & nd & \\
\hline \multirow{2}{*}{$\begin{array}{l}\text { P. seriata complex } \\
\text { including } P \text {. pungens, } P \text {. } \\
\text { fraudulenta }\end{array}$} & Western Scottland & $12-13$ & nd & $\sim 0.3$ & $\sim 0.25$ & $\sim 3$ & 110000 & nd & Fehling et al., 2006 \\
\hline & $\begin{array}{l}\text { Southern Bight of the } \\
\text { North Sea }\end{array}$ & $15.4 \pm 0.3$ & $34.50 \pm 0.03$ & $\begin{array}{l}2.4 \pm 1.8 \\
\text { decreasing }\end{array}$ & $0.56 \pm 0.17$ & $\begin{array}{l}2.2 \pm 2.8 \\
\text { increasing }\end{array}$ & $\begin{array}{l}9.2 \cdot 10^{3-} \\
2.8 \cdot 10^{4}\end{array}$ & $\begin{array}{l}\text { 82-108pg } \\
\mathrm{mL}^{-1}\end{array}$ & This study \\
\hline
\end{tabular}

Min-max, mean \pm standard deviation, $\mathrm{R}<0$ and $\mathrm{R}>0$ : negative and positive correlation with diatom abundance, respectively., nd $=$ no data 
